\title{
Labor Market Uncertainty and Private Sector Labor Supply in Russia
}

\author{
By: Steven Stillman
}

Working Paper Number 359

September 2000 


\title{
Labor Market Uncertainty and Private Sector Labor Supply in Russia*
}

\author{
Steven Stillman \\ RAND \\ Mail Stop M-15A \\ 1700 Main Street \\ P.O. Box 2138 \\ Santa Monica, CA 90407-2138 \\ USA
}

Tel: 310-393-0411 ext. 7719

Fax: 310-451-7061

Email: stillman@rand.org

September 2000

I would like to thank Shelly Lundberg, Elaina Rose, and Judith Thornton for extremely helpful comments and suggestions. I am also grateful to seminar participants at the Universities of Washington, Colorado Denver, and Auckland, and the EALE / SOLE World Conference 2000, for insightful discussions. 


\begin{abstract}
The development of a vibrant private sector has been one of the key failures of the transitional period in Russia. This paper develops a theoretical and empirical model of individual labor supply behavior under uncertainty, and estimates this model using data from the Russian Longitudinal Monitoring Survey for the years $1994-1996$ \& 1998. As hypothesized, a decrease in private sector earnings variability is estimated to increase the likelihood of private sector employment for individuals with constrained consumption smoothing ability. Evidence of ex-ante intra-household risk sharing is also found with individuals reducing their exposure to uncertainty by diversifying the portfolio of jobs held by their household.
\end{abstract}

Keywords: Private Sector, Labor Supply, Russia, Uncertainty, Intra-Household

JEL-Code: J23, P36, C35, D10 


\section{Non-Technical Summary}

In pre-transition Soviet Bloc economies, the state dominated the economy and the labor market. Because of this, it has been an extremely difficult proposition for these countries to encourage private enterprise. While the development of a vibrant private sector has started to take place in many of the transitional economies, its evolution so far has been anemic in Russia. Most previous research focuses on macroeconomic conditions or firm behavior to explain this phenomena. Instead, this paper uses representative panel data from the Russian Longitudinal Monitoring Survey (RLMS) for the years 1994 1996 \& 1998 to examine the determinants of private sector labor supply in Russia from the perspective of the individual.

In many countries, private sector jobs are considerably riskier than government sector jobs, as government jobs often include large pensions and other benefits. This is especially true in Russia where weak property rights and opaque tax rules create considerable uncertainty for private sector workers, and the legacy of communism has endowed government sector workers with special entitlements such as free housing and medical care. The underdevelopment of Russia's financial institutions may limit its citizens' ability to insure against private sector earnings variability by smoothing consumption across time (i.e. by borrowing and saving). Because of this, the higher variability of earnings in the private sector may discourage many individuals from participating in this sector. Thus, the sectoral labor supply model developed in this paper allows earnings variability to directly affect individual returns to working in a particular sector.

The main results of this paper are as follows. Private sector earnings variability is found to negatively affect labor supply to the private sector for individuals who have difficulty smoothing consumption. For individuals with the least ability to smooth consumption, a twelve hundred ruble decrease in private sector earnings variability (approx. 50 US\$ - 1998) increases the likelihood of private sector employment by $8 \%$. Individuals residing in households that have higher levels of assets, own a home or land, or are located in communities with better banking infrastructure are less affected by earnings variability and are more likely to work in the private sector. Individuals are also found to share 
risk within their household by diversifying the portfolio of jobs held by members (i.e. a common strategy is for one household member to work in the government sector and another in the private sector).

These results suggest that there is scope for government policy to increase labor supply to the private sector by improving certain institutions. As formal financial methods of consumption smoothing are found to be very important in reducing the effect of earnings variability, policies which encourage stability in the financial sector can also be expected to increase private sector participation. Continuing privatization of both land and the housing stock should encourage individuals to work in the private sector by providing additional liquid assets. While earning variability is not found to discourage private sector employment for the average worker, improving private sector infrastructure (property rights, tax codes, etc.) should increase private sector employment. It should be emphasized that other sources of private sector earnings variability, such as high returns to successful risk taking or entrepreneurship, should not be discouraged, as private sector development is often stimulated by the behavior of risktaking individuals.

The decision to work in the private sector is also affected by factors unobserved in this study, such connections developed under Communism and an individual's ability to adjust to a market economy. Also unaccounted for are features of the local labor market such as the demand for private sector workers in new enterprises, and the degree to which local mafias and governments discourage or encourage private sector employment. Future studies would ideally expand upon the model developed in this paper by including these other factors. Nonetheless, by deriving an individual sectoral labor supply model from microeconomic foundations and modeling how uncertainty affects individual decision-making, this paper has provided a unique perspective on the determinants of private sector labor supply in transitional economies. 


\section{I) Introduction}

In pre-transition Soviet Bloc economies, the state dominated the economy and the labor market. All individuals were employed by state firms, which provided such diverse services as childcare, housing, and medical facilities. ${ }^{1}$ Because of this, it has been an extremely difficult proposition for these countries to encourage private enterprise (Flanagan 1994). While the development of a vibrant private sector has started to take place in many of the transitional economies, its evolution so far has been anemic in Russia (Åslund 1997)? This paper analyzes private sector employment from the perspective of the individual decision-maker. ${ }^{\text {[ }}$ It develops a theoretical and empirical model of individual labor supply behavior and using representative panel data from the Russian Longitudinal Monitoring Survey (RLMS) for the years 1994 - 1996 \& 1998, estimates this model to examine the determinants of private sector labor supply in Russia.

In many countries, private sector jobs are considerably riskier than government sector jobs, as government jobs often include large pensions and other benefits. This is especially true in Russia where weak property rights and opaque tax rules create considerable uncertainty for private sector workers, and the legacy of communism has endowed government sector workers with special entitlements such as free housing and medical care. The underdevelopment of

\footnotetext{
${ }^{1}$ The Economist $\left(1998\right.$, Jan $\left.10^{\text {th }}\right)$ illustrates the role of a typical firm in the Soviet style economy and discusses the difficulties inherent in operating such a firm in a market economy.

${ }^{2}$ This paper calculates the private sector's share of total employment in Russia to be $27 \%$ in $1994-1996$, rising to $30 \%$ in 1998. In comparison, Flanagan (1994) finds it to be $45 \%$ in Poland and $35 \%$ in Hungary in 1994, and the OECD (1998) reports it to be 69\% in Sweden (the lowest in the OECD) and 87\% in the US in 1997.

${ }^{3}$ While many researchers have become interested in analyzing the determinants of private sector employment in transitional economies, so far, few papers have focused on individual behavior. Exceptions include Earle \& Sakova (1999), Foley (1997), and Boeri \& Flinn (1999).
} 
Russia's financial institutions may limit its citizens' ability to insure against private sector earnings variability by intertemporally smoothing consumption. Because of this, the higher variability of earnings in the private sector may discourage many individuals from participating in this sector. Thus, the sectoral labor supply model developed in this paper allows earnings variability to directly affect individual utility.

Empirically, an individual's sectoral labor supply decision is modeled as a function of: (1) The difference in expected earnings between sectors; (2) The difference in sectoral earnings variability, where the effect variability has on decision-making depends on the individual's ability to smooth consumption both intertemporally and within their household; and (3) Individual preferences towards a particular sector. This framework allows the paper to examine: (1) Whether individual labor supply responds to sectoral earnings differentials; (2) Whether higher earnings variability in the private sector discourages participation, and if so, which individuals are more affected by variability; and (3) Which individuals, once controlling for differences in expected earnings and earnings variability, are more likely to be employed in each sector due to individual preferences. Additionally, individual labor supply is modeled in the context of a risk sharing household, which allows the paper to indirectly test whether individuals ex-ante reduce their exposure to uncertainty by sharing income with other household members and diversifying the portfolio of jobs held by the household.

As anticipated, private sector earnings variability is found to negatively affect labor supply to the private sector for individuals who are hypothesized to have difficulty smoothing consumption. For individuals with the least ability to smooth consumption, a twelve hundred ruble decrease in private sector earnings variability (approx. 50 US\$ - 1998) increases the likelihood of private sector employment by $8 \%$. Individuals residing in households that have higher levels of assets, own a home or land, or are located in communities with better banking 
infrastructure are less affected by earnings variability. Significant evidence of ex-ante intrahousehold risk sharing is also found, and as expected, is more common in households with constrained consumption smoothing ability.

This paper continues as following. Section II develops the theoretical model of individual sectoral labor supply under uncertainty with underlies the empirical work in the paper. Section III outlines the econometric model and the estimation strategy. Section IV discusses how the individual sectoral labor supply model is extended to account for intra-household risk sharing. Section V describes the data used in the analysis. Section VI presents the results from the empirical analysis. Section VII then offers conclusions.

\section{II) Theoretical Model of Individual Sectoral Labor Supply under Uncertainty}

At the beginning of each time period, individuals choose whether to be employed in the government or private sector in order to maximize their expected utility of consumption. This allocation is assumed to be discrete and thus individuals cannot be simultaneously employed in both sectors. 1 An individual's expected utility of consumption is represented by the first two moments of the distribution of consumption. Assuming expected utility is represented by a mean-standard deviation (MS) model is particularly useful, as this paper will directly estimate how the measured distributions of sectoral earnings affect labor supply. ${ }^{\text {F }}$ Furthermore, Meyer

\footnotetext{
${ }^{4}$ Assuming that the sectoral allocation is discrete also implies that labor supply is inelastic. This restriction simplifies the theoretical model and allows for a straightforward estimation strategy. Evidence from Russia suggests that the total hours worked by an individual is often controlled by their employer and that labor earnings are often uncorrelated with hours worked (Commander \& McHale 1996). The RLMS data supports this assertion, as the correlation coefficient between hours and labor earnings is 0.11 . It also suggests that multiple job holding is relatively unimportant in Russia as only 7\% (11\%) of female (male) workers are employed at multiple jobs.

${ }^{5}$ Other options do exist here but, in general, are more restrictive than the MS framework.
} 
(1987) has demonstrated that a wide variety of functional forms for expected utility models are consistent with models incorporating MS rankings, as long as the stochastic payoff variables are distributed over similar cumulative distributions.

Thus, individuals maximize

$$
U_{i t}=V\left(\mu_{c i t}, \sigma_{c i t}\right), V_{\mu}>0, V_{\sigma}<0,
$$

where $\mu_{c}$ and $\sigma_{c}$ are the mean and standard deviation of consumption, $\mathrm{i}$ indexes individuals, and $\mathrm{t}$ indexes time. The mean of consumption is given by

$$
\mu_{c i t}=\mu_{y i t}
$$

where $\mu_{y}$ is the mean of earnings.

The mapping of the standard deviation of earnings to that of consumption depends on the degree to which individuals are able to smooth their consumption, either intertemporally and/or spatially across households or other communities. This ability to ex-post smooth consumption can depend on individual, household, and community characteristics. For example, Rosenzweig \& Binswanger (1993) find that for a sample of Indian households the correlation between consumption variability and ex-post income variability is highly dependent on the wealth of particular households, while Udry (1990) finds, for a sample of Nigerian households, that informal community lending is a major source of consumption insurance. Thus, the relationship between consumption and earnings variability is expressed as

$$
\sigma_{c i t}=\phi_{i t} * \sigma_{y i t}
$$

\footnotetext{
${ }^{6}$ Formally, all random variables must differ by only location and scale parameters, i.e. if $\mathrm{F}_{\mathrm{i}}(\mathrm{x})$ is the cumulative distribution of random variable $i$, then each random variable is said to meet the above condition if $F_{i}(x)=F_{j}(\alpha+\beta x)$ with $\beta>0$ for all $i \neq j$. Many two-parameter families of random variables such as the normal and uniform families meet this requirement.
} 
where $\sigma_{y}$ is the standard deviation of earnings, $0 \leq \phi_{i t} \leq 1$ and is an exogenously determined function of characteristics which influence the availability and cost of ex-post consumption smoothing methods.

The mean and standard deviation of earnings can be directly related to the distribution of earnings in the government and private sector,

$$
\begin{aligned}
& \mu_{y i t}=\alpha_{i t} \mu_{i t}^{p r}+\left(1-\alpha_{i t}\right) \mu_{i t}^{g v}, \\
& \sigma_{y i t}=\alpha_{i t} \sigma_{r}^{p r}+\left(1-\alpha_{i t}\right) \sigma_{r}^{g v},
\end{aligned}
$$

where $\alpha_{i t}=1(0)$ if an individual is employed in the private (government) sector, pr (gv) indicates the private (government) sector, and $\mathrm{r}$ indexes regions. While earnings are not realized until after an individual chooses their sector of employment, the first two moments of the return distribution for each sector are known to the individual (although not to the econometrician) prior to the decision.

The first moment of earnings in sector $\mathrm{S}$ (where $\mathrm{S}=\mathrm{gv}$ or $\mathrm{pr}$ ), $\mu_{i t}^{S}$, equals an individual's expected earnings, reflects their embodied human capital, and is equal to their marginal revenue product in that sector. The second moment of earnings in sector $\mathrm{S}, \sigma_{r}^{S}$, equals the standard deviation of an individual's transitory earnings in that sector. The distribution of individual transitory earnings in each sector is assumed to vary only by region. This assumption is necessary because data limitations make it impossible to estimate this distribution at the individual level. A regional measure is meaningful as many of the main factors which affect individual earnings variability vary significantly across regions in Russia $\square$ Three possible

\footnotetext{
${ }^{7}$ For example, regional governments have primary say in setting tax policy, enforcing contracts and property rights, and, in general, establishing the local business environment (The Economist 1998, Jan $3^{\text {rd }}$ ). Furthermore, regional
} 
sources of earnings variability in each sector are: (1) Earnings are correlated with firm profitability; (2) Hours worked are stochastic or controlled by employers; and (3) Employers fail to pay workers their complete earnings.

Combining equations (1) - (4), the sectoral labor supply model is analyzed by evaluating the utility function at the two alternative corner solutions. Thus, individual i chooses to work in the private sector at time $t$ if

$$
\alpha_{i t}=1: \text { if } V\left(\mu_{i t}^{p r}, \phi_{i t} * \sigma_{r}^{p r}\right)-V\left(\mu_{i t}^{g v}, \phi_{i t} * \sigma_{r}^{g v}\right)>0
$$

\section{III) Econometric Model \& Estimation Strategy}

\section{A) Estimating the Individual Sectoral Labor Supply Model}

The theoretical labor supply model developed in the previous section assumes that individuals choose in which sector to work solely by comparing their sectoral earnings distributions. However, individuals also may prefer to work in a particular sector for non-pecuniary reasons such as gaining sector-specific experience, receiving entitlements, or having the opportunity to undertake rent-seeking behavior. To capture this, a sector-specific preference parameter is included in each indirect utility function. Linearizing (5) (in percentage form), assuming that the parameters in the indirect utility function are additively separable, and defining $\Delta_{i t}$ as $\left(\frac{\Delta_{i t}^{p r}-\Delta_{i t}^{g v}}{\Delta_{i t}^{g v}}\right)$, where $\Delta_{i t}^{S}$ summarizes individual i's preferences for sector $\mathrm{S}$ at time t, individual $\mathrm{i}$ is expected to

governments typically decide which entitlements are available to government sector workers and directly influence whether they are paid by their employers.

${ }^{8}$ RLMS shows substantial evidence of back earnings with 52\% (21\%) of government (private) sector workers reporting that they are owed money by their employer. The high inflation levels experienced in Russia throughout the transitional period make delayed payment a very attractive option for firms. 
work in the private sector at time $t$ if

$$
\alpha_{i t}=1: \text { if } \delta_{1}\left(\frac{\mu_{i t}^{p r}-\mu_{i t}^{g v}}{\mu_{i t}^{g v}}\right)+\delta_{2} \phi_{i t}\left(\frac{\sigma_{r}^{p r}-\sigma_{r}^{g v}}{\sigma_{r}^{g v}}\right)+\Delta_{i t}>0
$$

Following the definition of the MS utility function (1), $\delta_{1}>0$ and $\delta_{2}<0$. While this expression is fully defined, none of the independent variables are observed by the econometrician and the dependent variable is observed only as a discrete outcome. In order to estimate this underlying model, further information is needed. It is assumed that $\Delta_{i t}$ is a function of individual and the household characteristics. As a first order approximation,

$$
\Delta_{i t}=\delta_{0}+Z_{1 i t} \delta_{3}+v_{i t}
$$

where $Z_{1 i t}$ is a vector of individual characteristics (including gender, height, weight, age, marital status, educational status, and the year), household demographics (including the number of children, elderly, other adults, and other workers), and residential location variables (including region, urbanicity, and city status) which may affect the non-pecuniary benefits available to the individual in each sector. The error term, $v_{i t}$ is assumed to be normally distributed mean zero and variance normalized to one.

\footnotetext{
${ }^{9}$ Educational status includes indicator variables for: (i) Some General Secondary Education (U.S. High School); (ii) Complete General Secondary Education (normal academic standard); (iii) Ordinary Vocational Diploma (lowest academic standard); (iv) Secondary Vocational Diploma (low academic standard); (v) Specialized Secondary Diploma (highest academic standard); (vi) Professional Course Diploma; and (vii) Institute / University Diploma. The eight regions represented are Moscow / St. Petersburg, Northern / North Western, Central / Central Black-Earth, Volga-Vaytski / Volga Basin (default), North Caucasian, Ural, West Siberian, and East Siberian / Far Eastern. City status includes indicator variables for: (i) Capital (Moscow) / Oblast Center (regional capital); (ii) Raion Center (major town); and (iii) Other (default). Summary statistics for all variables are available in appendix A.

${ }^{10}$ The discrete choice models in this paper are analyzed using maximum likelihood probit estimation which requires
} 
As discussed in section II, $\phi_{i t}$ represents an individual's ability to ex-post smooth consumption. Thus, as a first order approximation,

$$
\phi_{i t}=\gamma_{0}+Z_{2 i t} \gamma_{l}
$$

where $Z_{2 i t}$ is a vector of household characteristics (including whether a home is owned, the amount of land owned, the value of real household assets, and the amount of other household income) and community characteristics (including whether individuals can own private land, the availability of formal banking, and other bank characteristics) which may affect the availability and effectiveness of ex-post smoothing methods. ${ }^{\square}$ Substituting (7) \& (8) into (6), defining $\alpha_{i t}^{*}$ as the unobservable index function underlying $\alpha_{i t}$, and using $\ln \mu_{i t}^{p r}-\ln \mu_{i t}^{g v}$ as an approximation for $\frac{\mu_{i t}^{p r}-\mu_{i t}^{g v}}{\mu_{i t}^{g v}}$, the individual sectoral labor supply model can be re-written as

that the variance of the error term be normalized.

${ }^{11}$ The value of real household assets totals the estimated worth of the following assets: (1) Refrigerator; (2) Separate Freezer; (3) Washing Machine; (4) Black \& White TV; (5) Color TV; (6) VCR; (7) Car or Truck; (8) Motorcycle or Motorboat; (9) Tractor; (10) Garden Cottage; (11) Dacha (vacation home) or Other House; and (12) Other Apartment. The amount of other household income totals elderly pension income and household farm income in the previous month. The availability of formal banking includes indicator variables for: (i) No Banks; (ii) Only branch office of the Russian Federation Savings Bank (default); and (iii) Banks or branches besides RFSB. Other bank characteristics includes indicator variables for: (i): Depositor can withdraw 1,000 rubles out of their savings account by the next day; and (ii) Nearest non - RFSB bank or branch office is $<1$ mile away. Data on individual characteristics which are hypothesized to affect consumption smoothing ability are unavailable in RLMS. Detailed information on the construction of the consumption smoothing variables is available by request from the author. 


$$
\begin{aligned}
& \alpha_{i t}^{*}=\delta_{0}+\delta_{1}\left(\ln \mu_{i t}^{p r}-\ln \mu_{i t}^{g v}\right)+\gamma_{0} \delta_{2}\left(\frac{\sigma_{r}^{p r}-\sigma_{r}^{g v}}{\sigma_{r}^{g v}}\right)+Z_{2 \mathrm{it}} \gamma_{1} \delta_{2}\left(\frac{\sigma_{r}^{p r}-\sigma_{r}^{g v}}{\sigma_{r}^{g v}}\right)+Z_{1 \mathrm{it}} \delta_{3}+v_{i t}, \\
& \alpha_{i t}=1 \quad \text { if } \alpha_{i t}^{*}>0, \\
& \alpha_{i t}=0 \quad \text { if } \alpha_{i t}^{*} \leq 0 .
\end{aligned}
$$

Thus, individual sectoral labor supply is estimated as a function of: (1) The difference in individual expected sectoral earnings; (2) The difference in regional sectoral earnings variability, where the effect variability has on sectoral choice is a function of characteristics $\left(Z_{2 i t}\right)$ which may influence individual ex-post consumption smoothing ability; and (3) Characteristics $\left(Z_{1 i t}\right)$ which may be correlated with individual preferences towards a particular sector. Equation (9) can be estimated using a standard probit model once measures of expected earnings and earning variability are derived.

\section{B) Estimating Expected Sectoral Earnings}

Recalling section II, $\ln \mu_{i t}^{S}$ equals the expected $\log$ earnings of individual $\mathrm{i}$ at time $\mathrm{t}$ in sector $\mathrm{S}$. As in most traditional earnings models, log earnings is modeled as a linear function of observable determinants of human capital. The effect human capital has on earnings is also allowed to vary completely by sector. Thus, sectoral log earnings and expected log earnings are defined as,

$$
\begin{aligned}
& \ln Y_{i t}^{S}=\beta_{0}^{S}+X_{i t} \beta_{1}^{S}+u_{t}^{S}+u_{i t}^{S} ; \\
& \ln \mu_{i t}^{S}=E\left(\ln Y_{i t}^{S}\right)=\hat{\beta}_{o}^{S}+X_{i t} \hat{\beta}_{1}^{S},
\end{aligned}
$$

where $\ln Y_{i t}^{S}$ is $\log$ real earnings at individual i's primary job in the month prior to interview in year $\mathrm{t}$ and sector $\mathrm{S}$, and $X_{i t}$ is a vector of individual characteristics (including gender, height, weight, age, marital status, educational status) and residential location variables (including region, urbanicity, and city status), which may influence an individual's marginal productivity in either sector. The error term is decomposed into two parts: $u_{t}^{S}$, which is a fixed sector-year 
component to account for possible business cycle effects, and $u_{i t}^{S}$, which is an idiosyncratic component that is assumed to be normally distributed mean zero and variance $\sigma_{u}^{S}$. The fixed sector-year component is estimated using year dummy variables which are allowed to be correlated with $X_{i t}$.

Earnings are observed only for the sector in which individual $\mathrm{i}$ is employed in at time $\mathrm{t}$ and thus the sectoral earnings equations cannot be consistently estimated using ordinary least squares regression due to the endogeneity of sectoral choice (often referred to as selection bias). Furthermore, since a significant portion of adult Russians are not actively employed, observed earnings in each sector are obtained from a self-selected sample of individuals along this dimension. 1 It is assumed that individuals follow a sequential decision-making process; first choosing whether to work and then choosing in which sector to work ${ }^{13}$ Once specifying the reduced form participation and sectoral choice models, the sector-specific earnings equations are estimated by expanding, to account for multiple selection rules, the two-step procedure typically used to estimate ordinary selection bias models (Heckman 1979; Lee 1978). The selectioncorrected sector-specific earnings equations are then used to calculate expected sectoral earnings

\footnotetext{
$1230 \%(24 \%)$ of women (men) do not work in a given year, and $17 \%(12 \%)$ of women (men) never work in the sample period. Work is defined as having either worked positive hours or received some earnings in the past month. No distinction is made between being unemployed and being out of the labor force.

${ }^{13}$ Assuming that individuals follow a sequential decision-making process may be problematic as it does not allow for unobserved factors to simultaneously affect both participation decisions. To test the importance of this assumption, the two-step estimation procedure was modified with the selection equations estimated jointly (Tunali 1986). While this had a small effect on the expected sectoral earnings estimates, the results from the structural labor supply model were unaffected. This paper continues with the sequential decision-making assumption because of the computational intensity involved in estimating the joint selection model.
} 
for all individuals regardless of their actual sector of employment. Complete details on the reduced form selection models and the estimation procedure are available in appendix B.

Table 1 summarizes the identification of the earnings and reduced form selection equations. The selection terms and sector-specific earnings equations are readily identified since both of the selection equations include groups of variables which are uniquely excluded from the earnings equations. Community employment variables (including whether there is an employment service, whether government enterprises have been closed, and whether there is social welfare office) are included in the reduced form participation equation as they are assumed to affect an individual's reservation earnings. 4 These variables are excluded from both the earnings and the reduced form sectoral choice equations as they should not affect marginal productivity, ex-post consumption smoothing ability, or individual preferences towards a particular sector. Community characteristics are included in the reduced form sectoral choice equation as they are assumed to affect an individual's ex-post consumption smoothing ability. These variables are excluded from both the earnings and the reduced form participation equations as they should not affect marginal productivity, expected earnings, or reservation earnings.

\section{C) Measuring Sectoral Earnings Variability}

This paper proposes a measure of sectoral earnings variability which combines the information available on the intertemporal variability of each individual's transitory earnings with that on the

\footnotetext{
${ }^{14}$ An employment service may perform any of the following functions: (1) Help people find work; (2) Conduct retraining in a new specialization; and/or (3) Pay unemployment benefits. A community welfare office may: (1) Pay pensions; (2) Help people buy food; (3) Help people with housework or food preparation; and/or (4) Help people obtain medicines or medical services.
} 
cross-sectional variability of transitory earnings. ${ }^{\mathrm{L}}$ Earnings variability in sector $\mathrm{S}$ and region $\mathrm{R}$ is measured as the square-root of the average intertemporal variance of transitory earnings across individuals employed multiple years in that sector-region, where transitory earnings are defined as all residual earnings including year-specific earnings shocks ${ }_{6}$ Besides the justification discussed in section II, the region is also the most disaggregated level where a large number of observations are available in each cell (in this case, sector-region).

An individual's transitory earnings in a particular sector is measured as their total observed earnings minus their exponentiated expected log earnings in that sector. Thus, transitory earnings for individual $\mathrm{i}$ in sector $\mathrm{S}$ at time $\mathrm{t}$ is

$$
Y_{i t}^{T, S}=Y_{i t}^{S}-\exp \left(\hat{\beta}_{o}^{S}+X_{i t} \hat{\beta}_{1}^{S}\right)
$$

where $Y_{i t}^{S}$ is available only for the sector in which individual $\mathrm{i}$ is actual employed at time $\mathrm{t} .{ }^{\circ}$

\footnotetext{
${ }^{15}$ Ideally, sectoral earnings variability would be measured at the individual level. However, since individuals are observed for at most four years: (1) Any estimate of individual intertemporal earnings variability is expected to contain significant measurement error; and (2) Very few individuals (3\% of all workers) work multiple years in both sectors. This makes it unfeasible to measure earnings variability at the individual level.

${ }^{16}$ Gottschalk \& Moffitt (1994) introduce this methodology to measure what they call 'earnings instability'. I have adapted it slightly to measure what I define as 'sectoral earnings variability'.

${ }^{17}$ For instance, individual earnings variability could have been aggregated at the strata level. However, many of the 38 strata have less than 20 individuals in the private sector for whom intertemporal variability can be calculated, compared with an average of 125 (400) individuals in the private (government) sector when aggregated at the regional level. Furthermore, the results from the structural model are qualitatively similar when earnings variability is measured at this more disaggregated level.

18 This measure is used as a simple approximation. More accurately, transitory earnings equal an individual's observed earnings minus their expected earnings. Under the typical assumption that log earnings are distributed
} 
Sectoral earnings variability in region $\mathrm{R}$ is then calculated by averaging the intertemporal variance of transitory earnings for all individuals in sector $\mathrm{S}$ over that region and taking the square-root. $\frac{19}{\text { Thus, }}$

$$
\sigma_{r}^{S}=\sqrt{\frac{1}{N} \sum_{n} \frac{1}{(T-1)} \sum_{t}\left(Y_{i t}^{T, S}-\bar{Y}_{i}^{T, S}\right)^{2}} .
$$

Now, with appropriate measures of expected earnings and earnings variability, it is possible to estimate the individual structural labor supply model described in equation (9) via maximum likelihood probit analysis.

\section{IV) Modeling Household Sectoral Labor Supply}

\section{A) Modeling Intra-Household Risk Sharing}

One method that individuals can use to reduce consumption variability is to share resources with

normally, earnings are distributed log-normal and expected earnings equal $\exp \left(\hat{\beta}_{o}^{S}+X_{i t} \hat{\beta}_{1}^{S}+1 / 2 \hat{\sigma}_{u}^{2, S}\right)$. However, changing to this definition has no substantive effect on either the sectoral earnings variability estimates or on the results from the structural labor supply, and requires the additional estimation of the selection-corrected standard error of each log earnings equation.

${ }^{19}$ First, to allow for covariate shocks which equally affect transitory earnings in both sectors, the region-year average of transitory earnings is subtracted from each individual measure.

${ }^{20}$ This measure of sectoral earnings variability will be biased if: (1) Individual transitory earnings include timevarying measurement error (either due to random reporting error or the inclusion of an unobserved time-varying deterministic component); or (2) Individual sectoral choice is influenced by unobserved individual or regional characteristics which are correlated with sectoral earning variability (I thank Elaina Rose for bringing this point to my attention). Importantly, since individuals evaluate the difference in sectoral earnings variability which varies only across regions, the coefficients in the sectoral labor supply model will still be unbiased if earnings variability is biased consistently across sectors within regions or within sectors across regions. 
other household members. 1 Almost all of the previous empirical work which allows uncertainty to affect decision-making has used the household as the unit of observation? This has been justified by assuming that household members have common preferences and pool all sources of income. ${ }^{2}$ Directly modeling the interaction between individual household members is important as individuals can ex-ante reduce their exposure to labor market uncertainty by belonging to a household which shares any portion of earnings and holds a diversified portfolio of jobs.

Expanding on the individual sectoral labor supply model, individuals still maximize utility, but agree ex-ante to transfer a share of their realized income to other household members. The size of these transfers are set conditional on each individual's ex-post outcome, and are jointly decided on by the household prior to individual sectoral allocation. This transfer system is assumed the result of a cooperative Nash bargaining process (McElroy \& Horney 1981). There are several reasons why such an agreement may be self-enforcing, especially given the complex long-term nature of relationships between household members. ${ }_{24}$ Solving the Nash bargaining

\footnotetext{
${ }^{21}$ Household is defined in this paper as all individuals who live primarily together under one roof. In Russia these are typically nuclear or extended families.

${ }^{22}$ The only exception known to the author is Shaw (1987).

${ }^{23}$ Both the traditional common preference model and the unified household model are included here. This approach is often used because data is not available for all individuals within the household or because the outcome being studied cannot be disaggregated to the individual level. Importantly, the restrictions necessary to aggregate analysis to the household level have been rejected frequently in recent empirical work (Lundberg \& Pollak 1996).

${ }^{24}$ One argument against cooperative Nash bargaining is that individuals who receive positive earnings shocks have an incentive to cheat and refuse to share with their household members as agreed upon. However, since households are typically families, cooperative outcomes should be easier to achieve. Chakrabarti (1998) shows, in the context of migration with agreed upon remittances, how certain realistic trigger strategies can lead to cooperative equilibrium even when individuals are completely self-interested.
} 
problem, in the cooperative household each individual's sectoral labor supply is now a function of his/her own characteristics, the characteristics of all other household members, and implicitly, the threat point (the utility received when cooperation is not possible) of each individual in the household.

A change in any of the other household members' characteristics has an inconclusive effect on individual i's choice of employment sector. As earnings shocks are assumed to be uncorrelated across individuals in the same household, individuals in risk-sharing households face a decision between: (1) Diversifying the portfolio of jobs held by household members to exante decrease each individual's exposure to earnings variability; and (2) The opportunity cost of diversification, which is higher earnings, on average, for all household members. Thus, if the likelihood of one individual in the household working in the private sector increases, other members in the household may be more likely to work in the government sector if precautionary motives dominate (ex-ante insurance) or may be more likely to work in the private sector if the higher expected earnings of the first individual compensate for the additional earnings variability faced by all of the household members. Theoretically, it is impossible to determine which of these effects dominates. However, as ex-ante insurance results in lower earnings, on average, individuals in households with greater consumption smoothing ability should be less likely to hold a diversified portfolio of jobs.

\section{B) Estimating Household Sectoral Labor Supply}

As discussed above, analyzing individual sectoral labor supply in the context of a risk sharing household requires us to control for the individual characteristics of all other household members besides the individual under analysis. It is also necessary to assume that household composition 
is exogenously determined and is not affected by labor supply behavior. ${ }^{25}$ A convenient way of summarizing the characteristics of each individual is to calculate their expected sectoral labor supply when intra-household risk sharing is not possible. ${ }^{26}$ Thus, the expected sectoral labor supply of individual $i$ at time $t$ under autarky is

$$
\begin{aligned}
& \hat{\alpha}_{i t}^{*}=\Phi\left(\hat{\delta}_{0}+\hat{\delta}_{1}\left(\ln \mu_{i t}^{p r}-\ln \mu_{i t}^{g v}\right)+\hat{\gamma}_{0} \hat{\delta}_{2}\left(\frac{\sigma_{r}^{p r}-\sigma_{r}^{g v}}{\sigma_{r}^{g v}}\right)+Z_{2 i \mathrm{t}} \hat{\gamma}_{1} \hat{\delta}_{2}\left(\frac{\sigma_{r}^{p r}-\sigma_{r}^{g v}}{\sigma_{r}^{g v}}\right)+Z_{1 \mathrm{it}} \hat{\delta}_{3}\right), \\
& \hat{\alpha}_{i t}=1 \quad \text { if } \hat{\alpha}_{i t}^{*}>\bar{\alpha}_{r t}, \\
& \hat{\alpha}_{i t}=0 \quad \text { if } \hat{\alpha}_{i t}^{*} \leq \bar{\alpha}_{r t},
\end{aligned}
$$

where $\bar{\alpha}_{r t}$ is the mean number of workers in region $\mathrm{r}$ at time $\mathrm{t}$ employed in the private sector and $\Phi$ is the cumulative distribution function for a standard normal variable. The individual labor supply model (9) is then expanded to allow for household risk sharing by including as an independent variable the expected number of government sector workers in the household besides the individual under observation. Additionally, the number of other workers in the household is added as a consumption smoothing variable, $Z_{2 i t}$, since it may influence individual ex-post consumption smoothing ability. ${ }^{6-7}$ All other variables are identical to those in the individual structural model and the same procedure is used to estimate the household sectoral labor supply model.

\footnotetext{
${ }^{25}$ Anecdotal evidence suggests that mobility is limited for many Russians as the housing supply tends to be tightly controlled and many urban areas restrict mobility through the use of registration systems.

${ }^{26}$ This implicitly estimates each individual's threat point. The individual labor supply model (9) is estimated only for the sub-sample of households with one member and thus is properly specified.

${ }^{27}$ For example, an individual in a household with other workers may be perceived as more credit worthy by outside lenders, multi-worker households may be able to pool income to buy assets with high fixed entry costs (such as rental apartments), and/or other workers in the household may serve as a source of cheap loans to an individual.
} 


\section{V) Data}

All empirical work in this paper uses data from phase two of the Russian Longitudinal Monitoring Survey (RLMS) for the years 1994 - 1996 \& 1998 (Rounds V - VIII), which is a household-based representative survey of Russia collected by the Population Center at the University of North Carolina. ${ }^{28}$ The survey is designed as a repeated sample of each household dwelling. Thus, instead of following individuals or households from one year to the next, RLMS merely returns to the same dwelling sampled in the previous year. Consequently, by definition all households who move locally or migrate to another region are automatically lost to follow-up. Adding an additional twist to the sampling procedure, if the previous occupants of a sample dwelling are lost to follow-up, the new occupants are invited to join the survey sample. ${ }^{29}$ In each year, data is collected at the individual, household, and community level. ${ }^{0.0}$ The dataset used in all analyses includes all prime-age individuals, defined as men aged 18 to 59 and women aged 18 to 54 (considered the normal working ages for Russian men and women). After children and elderly are dropped from the dataset, the final sample consists of 9,239 individuals from 4,266 households, providing a total of 21,120 observations.

Individuals are asked to report both monetary and in-kind earnings collected, and hours worked during the last month at their primary, secondary, and other (self-employment) places of employment. An individual's main job is defined as the place of employment where they had

\footnotetext{
${ }^{28}$ The project description at www.cpc.unc.edu/rlms provides complete information about the RLMS survey and its sampling procedure.

${ }^{29}$ Heeringa (1997) provides additional information on attrition in RLMS and discusses its overall representiveness.

${ }^{30}$ All individuals in each household are surveyed with the exception of some elderly and very young members. Extensive data is collected for each of the 160 communities (sites). Information is provided to assign the 160 sites to 38 primary sampling units (PSUs) and to 8 regions.
} 
the highest total earnings or worked the most hours if earnings were equal. All analyses in this paper use only the data for this main job. Only individuals who had zero earnings and worked zero hours in all three job types are considered non-working. Individuals are also asked detailed information about each job. This information is used to classify the sector of employment at their main job. Many observers of Russia have hypothesized that most larger Russian enterprises behave similarly to state-owned firms, regardless of their ownership status, as they too, typically, face soft-budget constraints and primarily undergo rent-seeking activities (Åslund 1997). This paper focuses on labor supply to small private enterprises and self-employment, as small enterprise has little foundation in Russia, but is often considered the heart of the market economy. Thus, it uses a relatively strict definition of private sector employment, excluding all firms with partial government ownership or more than 200 employees. Appendix C provides additional information on how each worker's sector of employment is identified.

Currently, only price level data for metropolitan Moscow \& St. Petersburg is available from international sources. However, it is possible to use RLMS to calculate a regional price index. As part of the community surveys, a local citizen is sent out to collect data on the prices of a selection of store bought and market goods. Households are also asked to provide information on their expenditures in the week prior to the survey. This information is used to derive a regional price index which has 1998 Moscow \& St. Petersburg as the base region-year.

\section{VI) Results}

\section{A) Expected Sectoral Earnings \& Sectoral Earnings Variability}

The reduced form selection models (B1) \& (B2) and the selection-corrected sector-specific earnings equations (10) are estimated separately for rural and urban men and women, and

\footnotetext{
${ }^{31}$ Detailed information on the construction of this price index is available from the author by request.
} 
include a quintic in age as well as the variables noted. The results from the selection-corrected earnings equations are used to calculate expected sectoral earnings for all workers in each year regardless of their actual sector of employment and sectoral earnings variability in each region, and are available by request from the author. Table 2 presents these measures by region, along with other regional summary statistics. Consistent with apriori discussion, sectoral earnings variability and average expected earnings are found to be higher in the private sector in each of the eight regions.

As mentioned in section III, one concern about the measure of sectoral earnings variability used in this paper is that it may be correlated with regional characteristics and/or the regional composition of employment in each sector, which could lead to a reverse causality interpretation of the results from the structural labor supply model. Examining table 2 there appears to be no correlation between sectoral earnings variability in each region and other regional characteristics. For example, earnings variability is large in both sectors in the Northern / North Western region where households have high levels of assets, the banking infrastructure is average, and the private sector is fairly small. In each of these respects the Volga-Vaytski / Volga Basin region is quite similar, except in this region earnings variability is small in both sectors. Other examples of this lack of correlation are apparent in the table.

\footnotetext{
${ }^{32}$ Earning are imputed for individuals who report zero earnings at their main job only for use in estimating the log earnings equations (i.e. actual earnings are used in calculating transitory earnings). Using the available data on the hours worked at their main job, wage rates are calculated for all individuals who work positive hours and receive positive earnings. The wage rate at the $1^{\text {st }}$ percentile in a particular sector (multiplied by actual hours worked) is then used to impute earnings for all individuals with zero earnings in that sector. This is done to avoid biasing the sectoral earnings equations by leaving out these zero earnings workers who have missing log earnings.
} 


\section{B) The Sectoral Labor Supply Model}

Table 3 presents the results from three specifications of the structural labor supply model. In each case the dependent variable is whether or not an individual who works is employed in the private sector on their main job! 3 In all specifications probit models are estimated, data on individuals are pooled across time-periods, and the panel nature of the data is not exploited. Specification (1) estimates a traditional sectoral labor supply model which only controls for expected sectoral earnings and preferences. Specification (2) estimates the complete sectoral labor supply model which controls for sectoral earnings variability and consumption smoothing ability, and allows for intra-household risk sharing. Specification (3) expands the previous specification by including regional fixed effects, which control for any time-invariant regionspecific characteristics which affect private sector employment. Since earnings variability is also fixed by region, the coefficient on this term cannot be estimated in this specification. However, the coefficients on the cross products of the earnings variability term and the consumption smoothing characteristics can be estimated. In all specifications the marginal effect of each independent variable on private sector employment, estimated at its mean, is presented along with its bootstrapped standard error. ${ }^{6}$

\footnotetext{
${ }^{33}$ Multiple job holders are included in the sample, but only their main job is examined. They are more commonly employed in the private sector at their main job (47\% vs. 26\%) and typically are employed in both sectors. This may indicate that individuals use multiple job holding as an additional consumption smoothing method and suggests that individuals moving into the private sector attempt to hold on to their government sector job and its entitlements. ${ }^{34}$ For discrete variables the marginal effect is calculated as the change in the independent variable which occurs when the variable is switched from zero to one. The significance level of each variable is calculated using the percentile bootstrap method and does not directly depend on the estimated standard error. The bootstrapped standard errors are robust to both strata level and household level clustering and correlation among the error terms.
} 
The results are quite robust across all the specifications. The results below refer to specification (2), the household sectoral labor supply model without regional fixed effects, except when noted .5 Contrary to theory, in each specification, the coefficient on the difference in expected sectoral earnings is insignificant. This indicates that sectoral employment is not responsive on the margin to changes in individual expected sectoral earnings. While this result is contrary to basic utility maximization theory, it has also been found in other papers which examine sectoral labor supply behavior (Van der Gaag \& Vijverberg 1988; Dustmann \& van Soest 1998). In accordance with the theoretical model, a decrease in the difference in earnings variability is found to have a positive effect on the likelihood of private sector employment for individuals with constrained consumption smoothing ability. Since the difference in sectoral earnings variability is interacted with all variables assumed correlated with an individual's consumption smoothing ability, one must be careful in interpreting the coefficients.

For individuals who are predicted to have the least ability to ex-post smooth consumption (these are individuals in households which: (1) Do not own a home; (2) Do not own land; (3) Have real assets worth less than 40,001 rubles; (4) Have negative other income; and (4) Live in communities where: (a) Individuals cannot own private land; and (b) There are no banks), a twelve hundred ruble (approx. 50 US\$ - 1998) decrease in private sector earnings variability (or increase in government sector earnings variability) increases the probability of working in the private sector by $8 \%$ (significant at the $10 \%$ level). $\frac{3}{6}$ Characteristics which are expected to be

\footnotetext{
Appendix B.III provides additional information on the bootstrap method.

${ }^{35}$ This is the preferred specification as it follows directly from the theoretical model and allows all important coefficients to be estimated.

${ }^{36}$ A twelve hundred ruble increase in government sector variability or decrease in private sector variability is
} 
positively correlated with individual consumption smoothing ability (including home ownership, significant land ownership, higher levels of real household assets and other income, better banking infrastructure, and additional workers in the household) are found to reduce the effect earnings variability has on private sector employment. Some evidence of risk loving behavior is found as an increase in private sector earnings variability is estimated to increase the likelihood of private sector employment for individuals with strong consumption smoothing ability.

Significant evidence of intra-household risk sharing is also found, as the coefficient on the number of other workers in the household and on the number of other expected government sector workers (out of the total number of other adults) are each highly significant. This suggests that households attempt to diversify their employment portfolio in order to ex-ante reduce each member's exposure to earnings variability. Each additional expected government sector worker in a household, holding constant the number of workers, is found to increase an individual's likelihood of private sector employment by $3 \%$. Adding an additional member to a household, holding constant the ratio of private to government sector workers, increases the likelihood of government sector employment for all members.

After controlling for their direct effect on earnings, certain individual and household characteristics are found to have a significantly effect on an individual's likelihood of private sector employment. As found in Gimpelson \& Lippoldt (1999), males and the unmarried are more likely to be employed in the private sector. Having a specialized secondary diploma and/or a university diploma lowers an individual's likelihood of private sector employment. Two possible explanations for this are: (1) Individuals with formal education have significant human capital which is specific to the government sector; and (2) Individuals with formal education are

approximately equal to a $100 \%$ decrease in the difference in sectoral earnings variability evaluated at its mean. 
segregated into positions in the government sector which have significant non-pecuniary rewards, such as the opportunity to receive bribes. An individual's height in found to be positively correlated with their likelihood of private sector employment, with a $10 \mathrm{~cm}$ increase in height raising the likelihood by $2 \%$. It is speculated that this occurs because individuals employed in the private sector often need to deal with local mafias and other rent-seekers, and thus being taller and more intimidating may come in handy. ${ }^{\text {.7 }}$ As a possible sign of private sector growth, participation increased in 1998 with individuals $3-4 \%$ more likely to work in the private sector in this year compared with all others. The regional fixed effects in specification (3) clearly show that private sector employment is more common in certain regions. The regional dummy variables are highly significant with private sector employment $13-14 \%$ (69\%) more likely for individuals in Moscow / St. Petersburg, North Caucasia, and the Urals (North / North West, Central / Central Black-Earth, and West Siberia), than for those in East Siberia / Far East and the Volga-Vaytski / Volga Basin.

In each specification estimated above, it is assumed that household characteristics and household composition are exogenously given and are not influenced by the employment decisions of household members. However, an individual's realized earnings may directly affect the current value of household assets or the amount of land owned by the household, and may also influence the composition of the household. If either household characteristics or composition are endogenously determined, the results above may be biased. In order to examine the bias caused by these assumptions, two additional specifications of the sectoral labor supply model are estimated.

\footnotetext{
${ }^{37}$ I thank Judith Thornton for suggesting that height may be an important characteristic for private sector workers in Russia.
} 
The first attempts to control for the possible endogeneity of household characteristics by redefining these variables in each year to equal their value in each household's first year in the survey and then re-estimating the structural model dropping all observations from the household's first year. These new measures, while correlated with future values, are not affected by future sectoral choice decisions, and thus the results from this specification should be unbiased. The second attempts to control for the possible endogeneity of household composition by re-estimating the structural model using only individuals from the sample of households whose composition remained unchanged during the sample period. As successful individuals may choose to split-off from their household and form new households, and an individual's sector of employment is likely jointly determined with this decision, restricting analysis to sample subset where household composition remained unchanged will reduce this endogeneity problem. The results from both of these specifications are qualitatively similar to those in table 3, indicating that failing to control for either source of endogeneity does not cause significant bias. This supports the continuing use of specification (2) in table 3 as the preferred model.

\footnotetext{
${ }^{38}$ The robustness of the preferred model is also examined by estimating the following alternative specifications: (1) The earnings equations are estimated linearly instead of in log form and the difference in sectoral earnings variability is measured linearly instead of in percentage form; (2) The reduced form selection equations are estimated jointly; (3) All consumption smoothing variables are added to the estimated model linearly as well as being interacting with the measure of sectoral earnings variability; (4) All self-employed individuals are dropped from the entire estimation procedure; and (5) The structural model is estimated with individual sectoral employment transitions as the dependent variable instead of an individual's current sector of employment. In each alternative specification the results are qualitatively similar to those from the preferred model. Greater details on and results for each alternative specification are available from the author by request.
} 


\section{C) Allowing for Sub-Sample Heterogeneity}

Table 4 presents the results from estimating the preferred model on separate samples based on urbanicity, real household assets, land ownership, and household size. The effect sectoral earnings variability has on private sector labor supply varies a great deal across sub-groups. Increased private sector earnings variability is found to have a large negative effect on private sector employment for individuals in: (1) Landless rural households; (2) Low and medium real asset urban households; and (3) High real asset households in communities with weak financial sectors. For other groups such as: (1) Households in communities with strong banking sectors; (2) Households with large land holdings; and (3) Larger households, increased private sector variability encourages private sector employment. While larger land holdings appear to be very useful for smoothing consumption, real household assets and smaller land holdings are effective only for individuals in communities with strong financial sectors. This suggests that the liquidity of these assets is dependent on the strength of the local financial sector, and may indicate that these assets are typically used for collateral against financial borrowing and not to directly smooth consumption.

As household size increases, earnings variability is found to have a smaller effect on sectoral labor supply, suggesting that intra-household consumption smoothing is an effective risk sharing technique. The use of ex-ante intra-household risk sharing is also estimated to vary significantly across households. Sectoral employment diversification is found to be more common in rural households and in households where individuals are hypothesized to have difficulty smoothing consumption intertemporally. Since diversification results, on average, in lower overall earnings for the household, it should be less prevalent when cheap methods of intertemporal consumption smoothing are available. 


\section{D) Simulated Probabilities}

A useful way of examining the effect a particular independent variable has on the probability of private sector employment is to simulate a change in that variable, holding all other variables constant. Table 5 reports the results from such a simulation. Presented in row (1) is the probability of private sector employment when all independent variables are set at their mean. As indicated, the other rows present the probability of private sector employment when a particular variable of interest has been changed and all others have remained at their means.

For the average worker, moving from the region with the smallest difference in sectoral earnings variability $(50 \%)$ to the one with the largest $(213 \%)$ increases the likelihood of private sector employment by $5 \%$. This indicates that private sector earnings variability does not discourage private sector employment for the average worker. However, looking at the average worker disguises the fact that variability's effect on private sector employment varies greatly with an individual's ability to smooth consumption. An otherwise average worker facing the mean level of earnings variability, who lives in a household with low real assets, and which does not own a home or land, is $14 \%$ less likely to work in the private sector than an average worker who lives in a household with a high level of assets, and which owns a large amount of land and a home. This correlation between wealth and private sector employment is likely reinforcing, as earnings are, on average, $32 \%$ higher in the private sector. This should allow private sector workers to increase their household wealth, thus improving their ability to smooth consumption and increasing their likelihood of future private sector employment. Local banking infrastructure is also found to have a significant effect on private sector employment. An average worker who lives in a community with the best banking infrastructure is $11 \%$ more likely to be employed in the private sector than an average worker in a community without a local bank branch. 


\section{VII) Conclusions}

Economists have increasingly realized the importance of accounting for uncertainty when analyzing both individual and household behavior. The majority of empirical work in this area has focused on rural farm-based economies both because exogenous weather variability typically has a large effect on incomes and because many individuals are extremely vulnerable to adverse shocks. ${ }^{19}$ As discussed, Russians, as well as individuals in other transitional economies, are also likely to face high levels of uncertainty, as their country's private sector infrastructure and economic institutions are highly underdeveloped. This paper extends this important literature by examining how uncertainty affects sectoral labor supply in an unique country, one which is urban and industrialized, but has high levels of earnings variability and little market infrastructure.

As indicated in tables $3-5$, the effect earnings variability has on sectoral labor supply varies significantly across individuals and households. This suggests that there is scope for government policy to increase labor supply to the private sector by improving certain institutions. As formal financial methods of consumption smoothing are found to be very important in reducing the effect of earnings variability, policies which encourage stability in the financial sector can also be expected to increase private sector participation. Continuing privatization of both land and the housing stock should encourage individuals to work in the private sector by providing additional liquid assets. While earning variability is not found to discourage private sector employment for the average worker, improving private sector infrastructure (property rights, tax codes, etc.) should increase private sector employment. It should be emphasized that other sources of private sector earnings variability, such as high returns to successful risk taking or

\footnotetext{
${ }^{39}$ Morduch (1995) surveys this literature.
} 
entrepreneurship, should not be discouraged, as private sector development is often stimulated by the behavior of risk-taking individuals.

It is also crucial to note that while earnings variability is found to have a significant effect on sectoral labor supply, in general, the sectoral labor supply model does not explain much of the variation in individual sectoral choice. As seen in table 6, the estimated sectoral labor supply equation correctly predicts the employment sector for only $55 \%$ of Russian workers. It is likely that an individual's sectoral employment decision is affected by unobserved factors, such as the connections that they developed under Communism and their overall ability to adjust to a market economy. Other factors which are not accounted for in this paper, such as the demand for private sector workers in new enterprises, and the degree to which local mafias and governments discourage or encourage private sector employment are also expected to affect individual sectoral choice. Future studies would ideally expand upon the model developed in this paper by including these other factors. Nonetheless, by deriving an individual sectoral labor supply model from microeconomic foundations and modeling how uncertainty affects individual decisionmaking, this paper has provided a unique perspective on the factors which affect private sector labor supply in transitional economies. 


\section{References}

Åslund, Anders. 1997. "Observations on the Development of Small Private Enterprises in Russia." Post-Soviet Geography and Economics 38. no. 4: 191-205.

Boeri, Tito and Christopher J. Flinn. 1999. "Returns to Mobility in the Transition to a Market Economy." Journal of Comparative Economics 27 (March). no. 1: 4-32.

Chakrabarti, Rupa. 1998. "Models of Remittances and Migration With or Without Cooperation." Working Paper 98-05. Department of Economics. Wellesley College.

Commander, Simon and John McHale. 1996. "Unemployment and the Labor Market in Transition: A Review of the Experience in Eastern Europe and Russia." in Economic Transitions in Russia and the New States of Eurasia. Edited by Bartlomiej Kaminski: 277314.

Deaton, Angus. 1997. The Analysis of Household Surveys. Baltimore: The Johns Hopkins University Press.

Dustmann, Christian and Arthur van Soest. 1998. "Public and Private Sector Wages of Male Workers in Germany." European Economic Review 42: 1417-41.

Earle, John S. and Zuzana Sakova. 1999. "Entrepreneurship from Scratch: Lessons on the Entry Decisions into Self-Employment from Transitional Economies." IZA Discussion Paper 79 (December).

The Economist (London). 1998. "Socialism in One Company." 10 January: 58-9. . 1998. "Russia’s Other Governments." 3 January: 47-8.

Flanagan, Robert J. 1994. "Labor Market Responses to a Change in Economic System." in Proceedings of the World Bank Annual Conference on Development Economics 1994: 40525. 
Foley, Mark C. 1997. "Labor Market Dynamics in Russia.” Yale University Center Discussion Paper 780 (August).

Gimpelson, Vladimir, and Douglas Lippoldt. 1999. "Private Sector Employment in Russia." Economics of Transition 7. no. 2: 505-33.

Gottschalk, Peter and Robert Moffitt. 1994. "The Growth of Earnings Instability in the U.S. Labor Market.” Brookings Papers on Economic Activity 2: 217-72.

Hall P. 1992. The Bootstrap and Edgeworth Expansion. New York: Springer-Verlag.

Heckman, James. 1979. "Sample Selection Bias as a Specification Error." Econometrica 47 (January). no. 1: 153-62.

Heeringa, Steven G. 1997. "Russia Longitudinal Monitoring Survey Sample Attrition, Replenishment, and Weighting: Rounds V-VII.” University of Michigan Institute for Social Research (March).

Lee, Lung-Fei. 1978. "Unionism and Wage Rates: A Simultaneous Equations Model With Qualitative and Limited Dependent Variables." International Economic Review 19 (June). no. 2: 415-33.

Lundberg, Shelly and Robert A. Pollak. 1996. "Bargaining and Distribution in Marriage." Journal of Economic Perspectives 10 (Fall). no. 4: 139-58.

Maddala, G. S. 1983. Limited Dependent and Qualitative Variables in Econometrics. Econometric Society Monographs No .3. Cambridge, England: Cambridge University Press. McElroy, Marjorie B. and Mary Jean Horney. 1981. "Nash Bargained Household Decisions." International Economic Review 22 (June). no .2: 333-49.

Meyer, Jack. 1987. “Two-Moment Decision Models and Expected Utility Maximization." American Economic Review 77 (June). no. 3: 421-30. 
Morduch, Jonathan. 1995. "Income Smoothing and Consumption Smoothing." Journal of Economic Perspectives 9 (Summer). no. 3: 103-14.

OECD. 1998. "Public Sector Table 1.” National Accounts. Paris.

Rosenzweig, Mark R. and Hans P. Binswanger. 1993. "Wealth, Weather Risk, and the Composition and Profitability of Agricultural Investments." The Economic Journal 103 (January): 56-78.

Shaw, Kathryn L. 1987. “The Quit Propensity of Married Men.” Journal of Labor Economics 5. no. 4: $533-60$.

Tunali, İnsan. 1986. "A General Structure For Models of Double-Selection and An Application to a Joint Migration/Earnings Process With Remigration." in Research in Labor Economics 8B. Edited by Ronald G. Ehrenberg: 235-82.

Udry, C. 1990. "Credit Markets in Northern Nigeria: Credit as Insurance in a Rural Economy." World Bank Economic Review 4. no. 3: 251-69.

Van der Gaag, Jacques and Wim Vijverberg. 1988. “A Switching Regression Model For Wage Determinants in the Public and Private Sector of a Developing Country." The Review of Economics and Statistics : 244-52. 
Table 1 - Identification of the Earnings and Reduced Form Selection Equations

Variable Groups Included
Individual Characteristics
Household Demographics
Household Characteristics
Residential Location
Community Employment
Community Characteristics
Note: Individual characteristics include gender, height, weight, age, marital status, educational status, and the year; Household
demographics include the number of children, elderly, other adults, and other workers; Household characteristics include whether
a home is owned, the amount of land owned, the value of real household assets, and the amount of other household income;
Residential location variables include region, urbanicity, and city status; Community employment variables include whether there
is an employment service, whether government enterprises have been closed, and whether there is social welfare office; and
Community characteristics include whether individuals can own private land, the availability of formal banking, and other bank
characteristics.


Table 2 - Expected Sectoral Earnings and Sectoral Earnings Variability by Region

\begin{tabular}{|c|c|c|c|c|c|c|c|c|}
\hline Region & 1 & 2 & 3 & 4 & 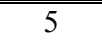 & 6 & 7 & 8 \\
\hline$\%$ Private Sector & $36 \%$ & $24 \%$ & $26 \%$ & $21 \%$ & $35 \%$ & $27 \%$ & $29 \%$ & $31 \%$ \\
\hline $\begin{array}{l}\text { Average \% Difference } \\
\text { In Expected Earnings }\end{array}$ & $86 \%$ & $45 \%$ & $92 \%$ & $82 \%$ & $40 \%$ & $93 \%$ & $51 \%$ & $58 \%$ \\
\hline $\begin{array}{l}\text { Transformed Avg. Exp. Log } \\
\text { Earnings in Private Sector }\end{array}$ & 2417 & 1571 & 2031 & 1612 & 1053 & 2233 & 1425 & 1426 \\
\hline $\begin{array}{l}\text { Transformed Avg. Exp. Log } \\
\text { Earnings in Gov't Sector }\end{array}$ & 1024 & 998 & 807 & 710 & 706 & 877 & 856 & 799 \\
\hline $\begin{array}{l}\% \text { Difference in Sectoral } \\
\text { Earnings Variability }\end{array}$ & $145 \%$ & $68 \%$ & $91 \%$ & $113 \%$ & $117 \%$ & $50 \%$ & $105 \%$ & $213 \%$ \\
\hline $\begin{array}{l}\text { Earnings Variability } \\
\text { In Private Sector (SD) }\end{array}$ & 2185 & 3215 & 1727 & 1922 & 2076 & 1507 & 3398 & 6069 \\
\hline $\begin{array}{l}\text { Earnings Variability } \\
\text { In Gov't Sector (SD) }\end{array}$ & 893 & 1916 & 904 & 901 & 956 & 1005 & 1657 & 1941 \\
\hline Complete General Sec. Ed. & $74 \%$ & $67 \%$ & $69 \%$ & $70 \%$ & $70 \%$ & $68 \%$ & $74 \%$ & $67 \%$ \\
\hline Institute / University Diploma & $38 \%$ & $18 \%$ & $24 \%$ & $21 \%$ & $20 \%$ & $16 \%$ & $20 \%$ & $21 \%$ \\
\hline Owns Home & $29 \%$ & $30 \%$ & $32 \%$ & $47 \%$ & $82 \%$ & $44 \%$ & $48 \%$ & $41 \%$ \\
\hline Land Owned (Hectares) & 0.04 & 0.05 & 0.13 & 0.22 & 0.29 & 0.05 & 0.08 & 0.95 \\
\hline Real Household Assets & 90463 & 127623 & 106370 & 133853 & 96230 & 108663 & 89413 & 92402 \\
\hline Other Income & 177 & 139 & 229 & 365 & 523 & 172 & 120 & 307 \\
\hline Site Has Employment Service & $100 \%$ & $77 \%$ & $79 \%$ & $79 \%$ & $60 \%$ & $87 \%$ & $81 \%$ & $77 \%$ \\
\hline Had Enterprises Closed & $100 \%$ & $71 \%$ & $40 \%$ & $53 \%$ & $58 \%$ & $51 \%$ & $36 \%$ & $62 \%$ \\
\hline Has A Social Welfare Office & $100 \%$ & $82 \%$ & $81 \%$ & $81 \%$ & $66 \%$ & $89 \%$ & $82 \%$ & $80 \%$ \\
\hline Can Own Private Land & $31 \%$ & $45 \%$ & $66 \%$ & $97 \%$ & $72 \%$ & $85 \%$ & $61 \%$ & $85 \%$ \\
\hline Site Has No Banks & $0 \%$ & $9 \%$ & $7 \%$ & $6 \%$ & $5 \%$ & $7 \%$ & $2 \%$ & $5 \%$ \\
\hline Site Only Has RFSB & $0 \%$ & $17 \%$ & $12 \%$ & $27 \%$ & $37 \%$ & $7 \%$ & $19 \%$ & $21 \%$ \\
\hline Has Branches Besides RFSB & $100 \%$ & $73 \%$ & $81 \%$ & $67 \%$ & $58 \%$ & $86 \%$ & $78 \%$ & $74 \%$ \\
\hline Can Withdraw Money Fast & $100 \%$ & $70 \%$ & $80 \%$ & $88 \%$ & $64 \%$ & $76 \%$ & $75 \%$ & $64 \%$ \\
\hline Has A Close Bank & $70 \%$ & $66 \%$ & $34 \%$ & $49 \%$ & $34 \%$ & $65 \%$ & $24 \%$ & $66 \%$ \\
\hline \# Worker-Years $(\mathrm{n} * \mathrm{t})$ & 1493 & 1162 & 2792 & 2694 & 1830 & 2418 & 1506 & 1549 \\
\hline \# Workers (n) & 795 & 524 & 1248 & 1132 & 898 & 1082 & 708 & 793 \\
\hline \# Workers in Private $>1 \mathrm{yr}$ & 118 & 61 & 156 & 121 & 124 & 137 & 96 & 95 \\
\hline \# Workers in Gov't > $1 \mathrm{yr}$ & 230 & 227 & 533 & 561 & 297 & 460 & 269 & 252 \\
\hline
\end{tabular}

Note: Region (1) Moscow / St. Petersburg; (2) Northern / North Western; (3) Central / Central Black-Earth; (4) Volga-Vaytski / Volga Basin; (5) North Caucasian; (6) Ural; (7) Western Siberian; and (8) Eastern Siberian / Far Eastern. Percent differences are private over government sector. All values are in real 1998 Moscow / St. Petersburg Rubles (1 USD $\cong 25$ Real Rubles). 
Table 3 - Structural Probit Models of Private Sector Labor Supply

\begin{tabular}{|c|c|c|c|}
\hline & (1) & (2) & (3) \\
\hline & \multicolumn{3}{|c|}{ Estimates of Marginal Effects (dF/dX) and Bootstrapped Standard Errors } \\
\hline \% Difference in Expected Earnings & $\begin{array}{r}-0.040 \\
(0.023)\end{array}$ & $\begin{array}{r}-0.052 \\
(0.025)\end{array}$ & $\begin{array}{r}-0.041 \\
(0.024)\end{array}$ \\
\hline$\%$ Difference in Earnings Variability & & $\begin{array}{r}-0.046 \\
(0.051)\end{array}$ & \\
\hline \multicolumn{4}{|c|}{ Consumption Smoothing Characteristics Interacted with \% Difference in Earnings Variability } \\
\hline Owns Home & & $\begin{array}{r}0.020 \\
(0.015)\end{array}$ & $\begin{array}{r}0.013 \\
(0.013)\end{array}$ \\
\hline Owns No Land & & $\begin{array}{l}0.014^{*} \\
(0.016)\end{array}$ & $\begin{array}{l}0.012 * \\
(0.014)\end{array}$ \\
\hline Owns $>1 / 5$ Hectare of Land & & $\begin{array}{l}0.071 * * * \\
(0.032)\end{array}$ & $\begin{array}{l}0.057^{* * *} \\
(0.031)\end{array}$ \\
\hline Real Household Assets $\leq 40,000$ Rubles & & $\begin{array}{r}-0.009 \\
(0.018)\end{array}$ & $\begin{array}{r}-0.009 \\
(0.016)\end{array}$ \\
\hline Real Household Assets $\geq 135,000$ Rubles & & $\begin{array}{l}0.026^{*} \\
(0.016)\end{array}$ & $\begin{array}{l}0.033^{* *} \\
(0.015)\end{array}$ \\
\hline Other Income Negative & & $\begin{array}{r}-0.001 \\
(0.019)\end{array}$ & $\begin{array}{r}0.001 \\
(0.017)\end{array}$ \\
\hline Other Income $\geq 800$ Rubles & & $\begin{array}{r}0.004 \\
(0.020)\end{array}$ & $\begin{array}{r}0.012 \\
(0.018)\end{array}$ \\
\hline Can Own Private Land & & $\begin{array}{r}-0.001 \\
(0.017)\end{array}$ & $\begin{array}{r}0.021 \\
(0.015)\end{array}$ \\
\hline Site Has No Banks & & $\begin{array}{r}-0.036 \\
(0.042)\end{array}$ & $\begin{array}{r}-0.027 \\
(0.039)\end{array}$ \\
\hline Has Branches Besides RFSB & & $\begin{array}{l}0.051^{* *} \\
(0.034)\end{array}$ & $\begin{array}{r}0.028 \\
(0.031)\end{array}$ \\
\hline Can Withdraw Money Fast & & $\begin{array}{r}0.019 \\
(0.019)\end{array}$ & $\begin{array}{l}0.022^{* *} \\
(0.018)\end{array}$ \\
\hline Has A Close Bank & & $\begin{array}{r}0.003 \\
(0.018)\end{array}$ & $\begin{array}{r}0.010 \\
(0.017)\end{array}$ \\
\hline \# Other Workers in Household & & $\begin{array}{r}0.001 \\
(0.014)\end{array}$ & $\begin{array}{r}0.003 \\
(0.015)\end{array}$ \\
\hline \multicolumn{4}{|c|}{ Household Demographics } \\
\hline \# Children in Household & $\begin{array}{r}-0.003 \\
(0.005)\end{array}$ & $\begin{array}{r}-0.005 \\
(0.006)\end{array}$ & $\begin{array}{r}-0.004 \\
(0.005)\end{array}$ \\
\hline \# Elderly in Household & $\begin{array}{l}-0.015^{*} \\
(0.008)\end{array}$ & $\begin{array}{r}-0.018 \\
(0.010)\end{array}$ & $\begin{array}{l}-0.023^{*} \\
(0.009)\end{array}$ \\
\hline \# Other Adults in Household & $\begin{array}{l}0.016^{* *} \\
(0.006)\end{array}$ & $\begin{array}{r}0.007 \\
(0.009)\end{array}$ & $\begin{array}{r}0.014 \\
(0.008)\end{array}$ \\
\hline \# Other Workers in Household & $\begin{array}{l}-0.034 * * * \\
(0.008)\end{array}$ & $\begin{array}{l}-0.042^{* *} \\
(0.013)\end{array}$ & $\begin{array}{l}-0.041^{* *} \\
(0.013)\end{array}$ \\
\hline $\begin{array}{l}\text { \# Other Expected Gov't Sector Workers } \\
\text { in Household }\end{array}$ & & $\begin{array}{l}0.031^{* *} \\
(0.013)\end{array}$ & $\begin{array}{r}0.005 \\
(0.012)\end{array}$ \\
\hline \multicolumn{4}{|c|}{ Year of Observation } \\
\hline Year Is 1995 & $\begin{array}{r}0.007 \\
(0.007)\end{array}$ & $\begin{array}{r}0.004 \\
(0.008)\end{array}$ & $\begin{array}{r}0.008 \\
(0.008)\end{array}$ \\
\hline Year Is 1996 & $\begin{array}{r}0.006 \\
(0.008)\end{array}$ & $\begin{array}{r}-0.002 \\
(0.009)\end{array}$ & $\begin{array}{r}0.001 \\
(0.009)\end{array}$ \\
\hline Year Is 1998 & $\begin{array}{l}0.035^{* * *} \\
(0.010)\end{array}$ & $\begin{array}{l}0.033^{* * *} \\
(0.011)\end{array}$ & $\begin{array}{l}0.038^{* * *} \\
(0.011)\end{array}$ \\
\hline Observations & 15444 & 15444 & 15444 \\
\hline Pseudo R-Squared & 0.0287 & 0.0277 & 0.0335 \\
\hline
\end{tabular}

Note: See note at end of table 3 (cont.). 
Table 3 (cont.) - Structural Probit Models of Private Sector Labor Supply

\begin{tabular}{|c|c|c|c|}
\hline & (1) & (2) & (3) \\
\hline & \multicolumn{3}{|c|}{ Estimates of Marginal Effects $(\mathrm{dF} / \mathrm{dX})$ and Bootstrapped Standard Errors } \\
\hline \multicolumn{4}{|c|}{ Individual Characteristics } \\
\hline \multirow[t]{2}{*}{ Male } & $0.033 *$ & 0.018 & $0.032 *$ \\
\hline & $(0.023)$ & $(0.029)$ & $(0.024)$ \\
\hline \multirow[t]{2}{*}{ Age } & -0.003 & -0.002 & -0.002 \\
\hline & $(0.003)$ & $(0.004)$ & $(0.003)$ \\
\hline \multirow[t]{2}{*}{ Age Squared } & -0.001 & -0.002 & -0.002 \\
\hline & $(0.005)$ & $(0.005)$ & $(0.005)$ \\
\hline \multirow[t]{2}{*}{ Height $(\mathrm{cm})$} & $0.003 * * *$ & $0.002 * * *$ & $0.002 * * *$ \\
\hline & $(0.001)$ & $(0.001)$ & $(0.001)$ \\
\hline \multirow[t]{2}{*}{ Weight (kg) } & 0.000 & 0.000 & $-0.001 *$ \\
\hline & $(0.000)$ & $(0.000)$ & $(0.000)$ \\
\hline \multirow[t]{2}{*}{ Married } & $-0.031 * * *$ & $-0.031 * * *$ & $-0.034 * * *$ \\
\hline & $(0.011)$ & $(0.012)$ & $(0.012)$ \\
\hline \multirow[t]{2}{*}{ Some General Secondary Education } & $-0.064 * *$ & $-0.065 * *$ & $-0.072 * * *$ \\
\hline & $(0.026)$ & $(0.026)$ & $(0.026)$ \\
\hline \multirow[t]{2}{*}{ Complete General Secondary Education } & $0.022 * *$ & $0.019 *$ & $0.020 *$ \\
\hline & $(0.010)$ & $(0.010)$ & $(0.010)$ \\
\hline \multirow[t]{2}{*}{ Ordinary Vocational Diploma } & -0.013 & -0.012 & -0.013 \\
\hline & $(0.012)$ & $(0.012)$ & $(0.012)$ \\
\hline \multirow[t]{2}{*}{ Secondary Vocational Diploma } & 0.003 & 0.005 & 0.002 \\
\hline & $(0.010)$ & $(0.010)$ & $(0.010)$ \\
\hline \multirow[t]{2}{*}{ Specialized Secondary Diploma } & $-0.022 * *$ & $-0.025 * *$ & $-0.026 * *$ \\
\hline & $(0.010)$ & $(0.010)$ & $(0.010)$ \\
\hline \multirow[t]{2}{*}{ Professional Course Diploma } & $0.021 *$ & $0.025 * *$ & $0.020^{*}$ \\
\hline & $(0.009)$ & $(0.009)$ & $(0.009)$ \\
\hline \multirow[t]{2}{*}{ Institute / University Diploma } & $-0.038 * * *$ & $-0.039 * * *$ & $-0.044 * * *$ \\
\hline & $(0.012)$ & $(0.012)$ & $(0.012)$ \\
\hline \multicolumn{4}{|c|}{ Residential Location Variables } \\
\hline \multirow[t]{2}{*}{ Urban } & 0.009 & 0.014 & 0.005 \\
\hline & $(0.034)$ & $(0.040)$ & $(0.036)$ \\
\hline \multirow[t]{2}{*}{ Capital / Oblast Center } & $0.057 * *$ & 0.015 & 0.025 \\
\hline & $(0.023)$ & $(0.029)$ & $(0.028)$ \\
\hline \multirow[t]{2}{*}{ Raion Center } & 0.035 & -0.004 & 0.005 \\
\hline & $(0.021)$ & $(0.026)$ & $(0.025)$ \\
\hline \multirow[t]{2}{*}{ Moscow / St. Petersburg } & $0.138^{* * *}$ & & $0.126^{*}$ \\
\hline & $(0.023)$ & & $(0.051)$ \\
\hline \multirow[t]{2}{*}{ Northern / North Western } & 0.014 & & $0.064 *$ \\
\hline & $(0.023)$ & & $(0.044)$ \\
\hline \multirow[t]{2}{*}{ Central / Central Black-Earth } & $0.057 * * *$ & & $0.088 * *$ \\
\hline & $(0.017)$ & & $(0.035)$ \\
\hline North Caucasian & $0.142 * * *$ & & $0.141 * * *$ \\
\hline & $(0.022)$ & & $(0.058)$ \\
\hline Ural & $0.062 * * *$ & & $0.129 * * *$ \\
\hline & $(0.018)$ & & $(0.040)$ \\
\hline West Siberian & $0.071 * * *$ & & $0.094 * *$ \\
\hline & $(0.024)$ & & $(0.045)$ \\
\hline East Siberian / Far Eastern & $0.089 * * *$ & & 0.010 \\
\hline & $(0.021)$ & & $(0.056)$ \\
\hline
\end{tabular}

Note: The difference in expected sectoral earnings and sectoral earnings variability are calculated using selection-corrected log earnings equations and are available by request from they author. Percent differences are private over government sector. The estimated standard errors are derived via bootstrapping, and are robust to both strata level and household level clustering and correlation among the error terms. For discrete variables the marginal effect is calculated as the change in the independent variable occurring when the variable is switched from zero to one. The significance level of each variable is calculated using the percentile bootstrap method and does not directly depend on the estimated standard error.

* Significant at the 10 percent level. ** Significant at the 5 percent level. *** Significant at the 1 percent level. 
Table 4 - Structural Probit Models of Private Sector Labor Supply by Sub-Sample

\begin{tabular}{|c|c|c|c|c|c|c|c|c|c|c|c|}
\hline & Rural & Urban & Low Asset I & Med. Asset & Hi Asset & No Land & ome Land I & ots Land & One Adult & Two Adult & Three + Adult \\
\hline & & & Estim & ates of Marg & sinal Effects & $(\mathrm{dF} / \mathrm{dX})$ & nd Bootstrap & ped Stand & ard Errors & & \\
\hline \multirow{2}{*}{ \% Difference in Expected Earnings } & -0.058 & $-0.122 * * *$ & -0.040 & $-0.062 *$ & -0.086 & -0.040 & -0.061 & $-0.116^{*}$ & -0.055 & -0.035 & $-0.081 * *$ \\
\hline & $(0.042)$ & $(0.028)$ & $(0.027)$ & $(0.026)$ & $(0.040)$ & $(0.027)$ & $(0.033)$ & $(0.047)$ & $(0.043)$ & $(0.024)$ & $(0.031)$ \\
\hline \multirow[t]{3}{*}{ \% Difference in Earnings Variability } & -0.050 & $-0.093 * * *$ & -0.029 & -0.068 & $-0.083 * * *$ & -0.019 & -0.063 & 0.061 & $-0.116^{* * *}$ & -0.027 & 0.033 \\
\hline & $(0.064)$ & $(0.072)$ & $(0.061)$ & $(0.071)$ & $(0.083)$ & $(0.050)$ & $(0.064)$ & $(0.129)$ & $(0.085)$ & $(0.064)$ & $(0.077)$ \\
\hline & \multicolumn{11}{|c|}{ Consumption Smoothing Characteristics Interacted with \% Difference in Earnings Variability } \\
\hline \multirow[t]{2}{*}{ Owns Home } & 0.010 & 0.019 & 0.017 & 0.019 & $0.028 * *$ & 0.011 & 0.027 & 0.038 & 0.016 & 0.023 & 0.017 \\
\hline & $(0.026)$ & $(0.015)$ & $(0.019)$ & $(0.023)$ & $(0.023)$ & $(0.019)$ & $(0.019)$ & $(0.045)$ & $(0.029)$ & $(0.017)$ & $(0.023)$ \\
\hline \multirow[t]{2}{*}{ Owns No Land } & $-0.036 * *$ & $0.034 * * *$ & 0.002 & 0.011 & $0.027 * *$ & & & & 0.022 & $0.023 * *$ & -0.017 \\
\hline & $(0.028)$ & $(0.018)$ & $(0.022)$ & $(0.025)$ & $(0.025)$ & & & & $(0.034)$ & $(0.018)$ & $(0.023)$ \\
\hline \multirow[t]{2}{*}{ Owns $>1 / 5$ Hectare of Land } & 0.036 & $0.099 * * *$ & 0.042 & 0.045 & $0.123 * * *$ & & & & $0.137 * * *$ & $0.071 * * *$ & $0.047 *$ \\
\hline & $(0.041)$ & $(0.040)$ & $(0.046)$ & $(0.042)$ & $(0.045)$ & & & & $(0.065)$ & $(0.034)$ & $(0.053)$ \\
\hline \multirow[t]{2}{*}{ Real Household Assets $\leq 40,000$ Rubles } & -0.020 & -0.012 & & & & -0.015 & -0.006 & -0.040 & -0.001 & $-0.018^{*}$ & 0.007 \\
\hline & $(0.027)$ & $(0.019)$ & & & & $(0.025)$ & $(0.024)$ & $(0.050)$ & $(0.039)$ & $(0.021)$ & $(0.024)$ \\
\hline \multirow[t]{2}{*}{ Real Household Assets $\geq 135,000$ Rubles } & -0.005 & $0.036^{* *}$ & & & & 0.035 & 0.023 & 0.046 & -0.008 & $0.046^{* * *}$ & 0.005 \\
\hline & $(0.042)$ & $(0.017)$ & & & & $(0.025)$ & $(0.020)$ & $(0.061)$ & $(0.040)$ & $(0.019)$ & $(0.025)$ \\
\hline \multirow[t]{2}{*}{ Other Income Negative } & -0.017 & $0.023 * *$ & -0.001 & -0.022 & 0.018 & -0.042 & 0.015 & $0.048^{*}$ & -0.025 & 0.004 & 0.000 \\
\hline & $(0.029)$ & $(0.021)$ & $(0.028)$ & $(0.026)$ & $(0.029)$ & $(0.031)$ & $(0.023)$ & $(0.052)$ & $(0.064)$ & $(0.021)$ & $(0.028)$ \\
\hline \multirow[t]{2}{*}{ Other Income $\geq 800$ Rubles } & 0.022 & $-0.029 * * *$ & -0.011 & 0.031 & -0.005 & 0.004 & -0.005 & 0.043 & -0.028 & 0.006 & 0.018 \\
\hline & $(0.028)$ & $(0.026)$ & $(0.032)$ & $(0.034)$ & $(0.041)$ & $(0.031)$ & $(0.027)$ & $(0.054)$ & $(0.041)$ & $(0.024)$ & $(0.037)$ \\
\hline \multirow[t]{2}{*}{ Can Own Private Land } & 0.020 & 0.006 & 0.007 & -0.008 & -0.004 & 0.014 & -0.019 & -0.057 & 0.014 & -0.001 & -0.007 \\
\hline & $(0.028)$ & $(0.017)$ & $(0.023)$ & $(0.025)$ & $(0.028)$ & $(0.021)$ & $(0.021)$ & $(0.057)$ & $(0.033)$ & $(0.019)$ & $(0.025)$ \\
\hline \multirow[t]{2}{*}{ Site Has No Banks } & -0.045 & & -0.011 & $-0.111 * * *$ & 0.046 & -0.010 & -0.046 & -0.038 & 0.022 & -0.028 & $-0.097 * *$ \\
\hline & $(0.047)$ & & $(0.051)$ & $(0.083)$ & $(0.117)$ & $(0.056)$ & $(0.069)$ & $(0.084)$ & $(0.095)$ & $(0.050)$ & $(0.070)$ \\
\hline \multirow[t]{2}{*}{ Has Branches Besides RFSB } & $0.069 * *$ & $0.068 * *$ & 0.030 & $0.078 * *$ & $0.118 * * *$ & 0.024 & $0.084 * * *$ & 0.053 & 0.061 & $0.056^{*}$ & 0.038 \\
\hline & $(0.037)$ & $(0.063)$ & $(0.034)$ & $(0.054)$ & $(0.061)$ & $(0.036)$ & $(0.050)$ & $(0.075)$ & $(0.071)$ & $(0.037)$ & $(0.050)$ \\
\hline \multirow[t]{2}{*}{ Can Withdraw Money Fast } & -0.002 & $0.034 * *$ & 0.024 & -0.008 & $0.049 * *$ & $0.035 * *$ & -0.002 & 0.023 & $0.034 * *$ & $0.025^{*}$ & 0.004 \\
\hline & $(0.030)$ & $(0.023)$ & $(0.024)$ & $(0.033)$ & $(0.031)$ & $(0.026)$ & $(0.022)$ & $(0.057)$ & $(0.035)$ & $(0.022)$ & $(0.028)$ \\
\hline \multirow[t]{2}{*}{ Has A Close Bank } & -0.021 & 0.009 & 0.021 & -0.015 & -0.017 & 0.018 & -0.020 & 0.035 & 0.034 & 0.009 & -0.024 \\
\hline & $(0.042)$ & $(0.018)$ & $(0.021)$ & $(0.029)$ & $(0.028)$ & $(0.020)$ & $(0.025)$ & $(0.084)$ & $(0.038)$ & $(0.018)$ & $(0.030)$ \\
\hline \multirow[t]{2}{*}{ \# Other Workers in Household } & 0.040 & -0.012 & 0.008 & 0.013 & -0.033 & -0.004 & 0.010 & 0.013 & & -0.057 & -0.001 \\
\hline & $(0.036)$ & $(0.019)$ & $(0.019)$ & $(0.031)$ & $(0.031)$ & $(0.020)$ & $(0.022)$ & $(0.070)$ & & $(0.039)$ & $(0.025)$ \\
\hline \multicolumn{12}{|c|}{ Household Demographics } \\
\hline \multirow[t]{2}{*}{ \# Elderly in Household } & -0.023 & -0.003 & -0.011 & $-0.039 * *$ & -0.015 & -0.015 & -0.010 & $-0.053 * *$ & -0.025 & -0.008 & $-0.033 * *$ \\
\hline & $(0.017)$ & $(0.011)$ & $(0.013)$ & & $(0.017)$ & $(0.014)$ & $(0.012)$ & $(0.028)$ & & $(0.012)$ & $(0.017)$ \\
\hline \multirow{2}{*}{ \# Other Workers in Household } & $-0.081^{*}$ & -0.025 & $-0.055^{* *}$ & $-0.058^{*}$ & 0.001 & $-0.039 *$ & -0.047 & -0.063 & & 0.010 & -0.019 \\
\hline & $(0.029)$ & $(0.016)$ & $(0.018)$ & $(0.026)$ & $(0.027)$ & $(0.017)$ & $(0.020)$ & $(0.056)$ & & $(0.029)$ & $(0.021)$ \\
\hline \# Other Expected Gov't Sector Workers & $0.050 * *$ & 0.018 & $0.044 * * *$ & 0.003 & 0.023 & $0.038^{*}$ & 0.017 & 0.018 & & 0.039 & 0.023 \\
\hline in Household (Estimated Under Autarky) & $(0.021)$ & $(0.015)$ & $(0.015)$ & $(0.023)$ & $(0.021)$ & $(0.017)$ & $(0.017)$ & $(0.037)$ & & $(0.017)$ & $(0.017)$ \\
\hline Obse & 4322 & & 7715 & & 3921 & 7600 & 6550 & 1294 & 2194 & 9009 & 4241 \\
\hline Pseudo R-Squared & 0.0375 & 0.0344 & 0.0263 & 0.0395 & 0.0417 & 0.0302 & 0.0319 & 0.0701 & 0.0459 & 0.0303 & 0.0329 \\
\hline
\end{tabular}

Note: The difference in expected sectoral earnings and sectoral earnings variability are calculated using selection-corrected log earnings equations and are available by reques from they author. Percent differences are private over government sector. The estimated standard errors are derived via bootstrapping, and are robust to both strata level and household level clustering and correlation among the error terms. For discrete variables the marginal effect is calculated as the change in the independent variable occurring when the variable is switched from zero to one. The significance level of each variable is calculated using the percentile bootstrap method and does not directly depend on the estimated standard error. Each specification includes all variables included in specifications 2 in table 3 . Significant at the: * 10 percent level. ** 5 percent level. *** 1 percent level. 


\section{Table 5 - Simulated Probability of Private Sector Employment}

\begin{tabular}{|c|c|c|}
\hline \multirow{3}{*}{$\begin{array}{l}\text { All Independent Variables } \\
\text { Set At Their Mean }\end{array}$} & \multicolumn{2}{|c|}{ Probability of Private Sector Employment Conditional on Participation } \\
\hline & \multicolumn{2}{|c|}{$27.4 \%$} \\
\hline & Lowest Value of \% Difference & Highest Value of \% Difference \\
\hline $\begin{array}{l}\text { Change in \% Difference } \\
\text { in Sectoral Earnings Variability }\end{array}$ & $25.5 \%$ & $30.8 \%$ \\
\hline & Low Assets \& No Home or Land & High Assets \& Own Home \& Lots Land \\
\hline $\begin{array}{l}\text { Change in Real Household Income, } \\
\text { Other Income, Home Ownership, and } \\
\text { Land Ownership }\end{array}$ & $25.2 \%$ & $38.7 \%$ \\
\hline \multirow{3}{*}{ Change in Community Bank Status } & Has No Bank in Community & Has Close \& Fast Non-RFSB Bank \\
\hline & $18.5 \%$ & $29.5 \%$ \\
\hline & Government Sector Expected & Private Sector Expected \\
\hline $\begin{array}{l}\text { Change in Other Worker's Expected } \\
\text { Sector Of Employment in Household } \\
\text { w/ One Other Worker }\end{array}$ & $27.9 \%$ & $24.9 \%$ \\
\hline & Both Government Sector Expected & Both Private Sector Expected \\
\hline $\begin{array}{l}\text { Change in Other Worker's Expected } \\
\text { Sector Of Employment in Household } \\
\text { w/ Two Other Worker }\end{array}$ & $27.6 \%$ & $21.7 \%$ \\
\hline
\end{tabular}


Table 6 - Actual Versus Predicted Sector of Employment

\begin{tabular}{c|cc}
\hline \hline $\mathrm{N}^{*} \mathrm{~T}=15444$ & \multicolumn{2}{|c}{ Predicted Sector of Employment } \\
\hline Actual Sector of Employment & Government & Private \\
& 6130 & 5004 \\
Government & $39.7 \%$ & $32.4 \%$ \\
\multirow{2}{*}{ Private } & 1950 & 2360 \\
& $12.6 \%$ & $15.3 \%$ \\
\hline
\end{tabular}

Note: Predicted sector of employment is calculated using the estimated coefficients from specification (2) in table 3. The mean number of private sector workers in each region is used as the cutoff for determining each individual's predicted employment sector. 


\section{Appendix A - Summary Statistics}

Table A1 - Summary Statistics for the Entire Sample

\begin{tabular}{|c|c|c|c|}
\hline Variables $(\mathrm{N}=9239, \mathrm{~N} * \mathrm{~T}=21120)$ & Mean & Min. / Max. & Standard Deviation \\
\hline Individual Works & $73 \%$ & & 0.44 \\
\hline Worker Is Employed In Private Sector & $28 \%$ & & 0.45 \\
\hline Real Earnings For Workers in Government Sector & 1,260 & $0 / 48,407$ & 1,684 \\
\hline Real Earnings For Workers in Private Sector & 1,727 & $0 / 56,672$ & 2,816 \\
\hline Year is 1994 & $28 \%$ & & 0.45 \\
\hline Year is 1995 & $26 \%$ & & 0.44 \\
\hline Year is 1996 & $23 \%$ & & 0.42 \\
\hline Year is 1998 & $22 \%$ & & 0.42 \\
\hline Male & $49 \%$ & & 0.50 \\
\hline Age & 37 & $18 / 59$ & 11 \\
\hline Height $(\mathrm{cm})$ & 168 & $113 / 201$ & 9 \\
\hline Weight (kg) & 72 & $29 / 190$ & 14 \\
\hline Married & $74 \%$ & & 0.44 \\
\hline Some General Secondary Education & $96 \%$ & & 0.21 \\
\hline Complete General Secondary Education & $69 \%$ & & 0.46 \\
\hline Ordinary Vocational Diploma & $14 \%$ & & 0.35 \\
\hline Secondary Vocational Diploma & $24 \%$ & & 0.43 \\
\hline Specialized Secondary Diploma & $29 \%$ & & 0.46 \\
\hline Professional Course Diploma & $32 \%$ & & 0.47 \\
\hline Institute / University Diploma & $19 \%$ & & 0.40 \\
\hline \# Children & 0.84 & $0 / 8$ & 0.95 \\
\hline \# Elderly & 0.28 & $0 / 3$ & 0.55 \\
\hline \# Other Adults & 1.27 & $0 / 6$ & 0.89 \\
\hline \# Other Workers & 0.91 & $0 / 6$ & 0.77 \\
\hline Owns Home & $46 \%$ & & 0.50 \\
\hline Amount of Land Owned (Hectares) & 0.21 & $0 / 254$ & 4.38 \\
\hline Real Household Assets & 103,065 & $0 / 1,238,611$ & 142,744 \\
\hline Other Income & 302 & $-20,673 / 58,778$ & 1,491 \\
\hline Region is Moscow / St. Petersburg & $9 \%$ & & 0.29 \\
\hline Northern / North Western & $7 \%$ & & 0.26 \\
\hline Central / Central Black-Earth & $18 \%$ & & 0.38 \\
\hline Volga-Vaytski / Volga Basin & $17 \%$ & & 0.38 \\
\hline North Caucasian & $13 \%$ & & 0.34 \\
\hline Ural & $15 \%$ & & 0.36 \\
\hline West Siberian & $10 \%$ & & 0.30 \\
\hline East Siberian / Far Eastern & $10 \%$ & & 0.30 \\
\hline Urban & $70 \%$ & & 0.46 \\
\hline Lives In Capital / Oblast Center & $41 \%$ & & 0.49 \\
\hline Raion Center & $36 \%$ & & 0.48 \\
\hline Other & $23 \%$ & & 0.42 \\
\hline Site Has Employment Service & $79 \%$ & & 0.41 \\
\hline Had Enterprises Closed & $55 \%$ & & 0.50 \\
\hline Has A Social Welfare Office & $81 \%$ & & 0.39 \\
\hline Can Own Private Land & $72 \%$ & & 0.45 \\
\hline Site Has No Banks & $6 \%$ & & 0.24 \\
\hline Site Only Has RFSB & $19 \%$ & & 0.39 \\
\hline Has Branches Besides RFSB & $75 \%$ & & 0.43 \\
\hline Can Withdraw Money Fast & $77 \%$ & & 0.42 \\
\hline Has A Close Bank & $49 \%$ & & 0.50 \\
\hline
\end{tabular}

Note: All Values in Real 1998 Moscow / St. Petersburg Rubles (1 USD $\cong 25$ Real Rubles) 


\section{Appendix B - Estimation Details}

\section{I) The Reduced Form Selection Equations}

This paper does not attempt to explicitly model the individual's participation decision and instead relies upon a reduced form model of behavior. An individual decides whether or not to work by comparing their average expected earnings to their reservation earnings. Thus, all individual, household, and community characteristics which may influence either average expected or reservation earnings are included as independent variables in the reduced form participation model. Defining $W_{i t}^{*}$ as the unobservable index function underlying individual i's decision whether to work at time $\mathrm{t}$, the reduced form equation is specified as

$$
\begin{array}{ll}
W_{i t}^{*}=\xi_{0}+Z_{3 \mathrm{it}} \xi_{1}+e_{2 i t}, \\
W_{i t}=1 \quad \text { if } W_{i t}^{*}>0, \\
W_{i t}=0 & \text { if } W_{i t}^{*} \leq 0,
\end{array}
$$

where $W_{i t}=1$ if individual $\mathrm{i}$ is employed at time $\mathrm{t}$ and equals zero otherwise, and $Z_{3 i t}$ is a vector of individual characteristics, household demographics, household characteristics, community employment variables, and residential location variables. The error term, $\mathrm{e}_{2 \mathrm{it}}$, is assumed to be normally distributed mean zero and variance normalized to one.

The reduced form sectoral choice model can be found by substituting the sectoral earnings equations (10) into the structural labor supply equation (9). Recognizing that $\left(\frac{\sigma_{r}^{p r}-\sigma_{r}^{g v}}{\sigma_{r}^{g v}}\right)$ is constant within regions results in the following reduced form equation,

$$
\alpha_{i t}^{*}=\psi_{0}+X_{i t} \psi_{1}+\left(\mathrm{Z}_{2 \mathrm{it}} \otimes R_{i}\right) \psi_{2}+\mathrm{Z}_{1 i t}^{*} \psi_{3}+e_{1 i t}
$$

where $R_{i}$ is a vector of regional dummy variables and $Z_{1 i t}^{*}$ includes all variables in $Z_{1 i t}$ which are 
not already included in $X_{i t} \cdot{ }^{40}$ The error term, $\mathrm{e}_{1 \mathrm{it}}$, is assume to be normally distributed mean zero and variance normalized to one.

\section{II) Estimating the Selection-Corrected Sector-Specific Earnings Equations}

Conditional on observability, dropping sector subscripts, and combining all parameters and variables into single vectors, expected log earnings in the private sector is

$$
E\left[\ln Y_{i t} \mid W_{i t}=1, \alpha_{i t}=1\right]=X_{i t}^{*} \beta-b_{\lambda 1} \lambda_{1 i t}\left(Z_{3 i t}^{*} \xi\right)-b_{\lambda 2} \lambda_{2 i t}\left(Z_{2 i t}^{*} \psi\right),
$$

where $\lambda_{k i t}\left(\Psi_{\mathrm{it}}\right)=\frac{\phi\left(\Psi_{i t}\right)}{\Phi\left(\Psi_{i t}\right)}$ for $\mathrm{k}=1 \& 2$ (commonly referred to as the inverse Mill's ratio), and $\phi$ and $\Phi$ are, respectively, the density and distribution function for a standard normal variable (Maddala 1983, p. 282). Similarly, conditional on observability, expected log earnings in the government sector is

$$
E\left[\ln Y_{i t} \mid W_{i t}=1, \alpha_{i t}=0\right]=X_{i t}^{*} \beta-b_{\lambda 1} \lambda_{1 i t}\left(Z_{3 i t}^{*} \xi\right)+b_{\lambda 2} \lambda_{2 i t}\left(Z_{2 i t}^{*} \psi\right),
$$

where $\lambda_{\text {lit }}\left(\Psi_{\mathrm{it}}\right)=\frac{\phi\left(\Psi_{i t}\right)}{\Phi\left(\Psi_{i t}\right)}$ and $\lambda_{2 i t}\left(\Psi_{\mathrm{it}}\right)=\frac{\phi\left(\Psi_{i t}\right)}{1-\Phi\left(\Psi_{i t}\right)}$. The parameters of the sector-specific log earnings equations are consistently estimated by the following procedure: (1) Estimate the two reduced form selection equations (B1) \& (B2) using maximum likelihood probit estimation which produces consistent estimates of $\xi$ and $\psi$; (2) Use these parameter estimates to compute $\hat{\lambda}_{k i t}\left(\hat{\Psi}_{i t}\right)$ for each observation in the sample; and (3) Estimate $\beta$ and $b_{\lambda k}$ in each sectoral earnings

\footnotetext{
${ }^{40}$ In the empirical work, the cross product terms between $\mathrm{Z}_{2 \mathrm{it}}$ and $\mathrm{R}_{\mathrm{i}}$ are ignored constraining $\psi_{2}$ to be equal across regions. Thus, $\alpha_{i t}^{*}=\psi_{0}+X_{i t} \psi_{1}+\mathrm{Z}_{2 \mathrm{it}} \psi_{2}+\mathrm{Z}_{1 i t}^{*} \psi_{3}+e_{1 i t}$ is estimated instead of (B2). This is done because the cross product terms greatly reduce the available degrees of freedom and efficiency of the estimation, and have no qualitative effect on the expected earnings estimates.
} 
equation (10) by least squares regression of $\ln Y_{i t}$ on $X_{i t}^{*}$ and $\hat{\lambda}_{k i t}$.

\section{III) Bootstrap Standard Errors \& Confidence Intervals}

The estimated covariance matrices for the parameters in the structural labor supply models are incorrect as they do not account for the fact that expected earnings and earnings variability are previously estimated. Since estimation occurs in three steps it is not possible to calculate asymptotically correct standard errors in a straightforward way. This paper uses a bootstrap method to calculate correct standard errors for all of the estimated structural labor supply models. Bootstrapping, in general, can be used to recover the distribution of any defined statistic by exploiting the fact that the sample observations are a random sample of the overall population (Hall 1992). Thus, any random sample (with replacement) of the observed sample is also a random sample of the overall population. The bootstrap method proceeds as follows: (1) A random sample of size $\mathrm{N}$ (all observations) is drawn with replacement from the observed sample; (2) The statistics of interest are calculated; (3) The process is repeated q times, with the value of the statistics noted each time; and (4) Given these bootstrapped estimates of the sampling distributions of the statistics, standard errors and confidence intervals are constructed. Accordingly, the standard errors for the coefficients in the sectoral labor supply models are calculated by first constructing 1000 bootstrap samples and then estimating the entire three-step model on each of these datasets, noting the resulting coefficients. The distribution of each coefficient is then used to calculate its correct standard error and confidence interval.

\footnotetext{
${ }^{41}$ One assumption necessary with bootstrapping is the independence of observations in the dataset. In general, all datasets which use complex survey sampling methods violate this assumption (Deaton 1997; p.60). This paper makes two modifications to the simple bootstrap in order to apply it to the RLMS dataset. First, resampling is done independently within strata. Second, instead of resampling individuals, the procedure takes a weighted resample
} 


\section{Appendix C - Sector of Employment}

Individuals are asked detailed information about each of their jobs, which is used to classify the sector of employment. An individual is considered to work in the private sector at their main job

if: (1) Their main job is other economic activity (such as sewing dresses, being a driver or delivery person, or doing household chores or repairs); (2) For their main job, they answered "no" to the question, "Do you work at an enterprise, organization, institution, collective farm, state farm, or firm?" and they are not in the army; (3) For their main job, they answered "yes" to the question, "What do you think, do you work at your own enterprise?" or (4) For their main job they answered "no" to the question "Is the government the owner or co-owner of your enterprise or organization?" they reported $\leq 200$ workers at their place of employment, and they are not in the army. All individuals who answered these questions and who are not classified into the private sector are considered employed in the government sector at their main job. Not enough information is available to classify $7 \%$ of the main jobs. These are imputed by first using the job sector calculated in a previous or future year for individuals who report starting their current job before the year in question (56\% of the imputations). Jobs which are still unclassified are then imputed using the predicted probabilities from a probit model which includes as independent variables; indicators of the individual's occupation, the year they started the job, the number of employees at the job, and the region and year of observation. ${ }^{2}$

(weighted by the number of years the household is in the dataset) of the households in the dataset (splitoffs are included in their original households) and keeps all observations for a particular household when that household is selected. This procedure accounts for the observational dependence which is caused by both the clustered nature of the sampling procedure and the panel nature of the dataset.

${ }^{42}$ The percentage of individuals employed in the private sector in each region-year is used as the threshold value for the imputation. 


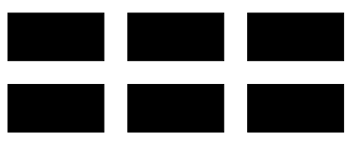

THE WiLliam DAVIDSON INSTITUTE

AT THE UNIVERSITY OF MICHIGAN BUSINESSSCHOOL

\section{DAVIDSON INSTITUTE WORKING PAPER SERIES - Most Recent Papers}

The entire Working Paper Series is available at: www.wdi.bus.umich.edu

CURRENT AS OF $1 / 25 / 01$

\begin{tabular}{|c|c|c|}
\hline Publication & Authors & Date \\
\hline $\begin{array}{l}\text { No. } 359 \text { Labor Market Uncertainty and Private Sector Labor Supply in } \\
\text { Russia }\end{array}$ & Steven Stillman & Sept. 2000 \\
\hline $\begin{array}{l}\text { No. } 358 \text { Russian Roulette-Expenditure Inequality and Instability in } \\
\text { Russia, 1994-1998 }\end{array}$ & Branko Jovanovic & Sept. 2000 \\
\hline No. 357 Dealing with the Bad Loans of the Chinese Banks & John P. Bonin and Yiping Huang & Jan. 2001 \\
\hline No. 356 Retail Banking in Hungary: A Foreign Affair? & John P. Bonin and István Ábel & Dec. 2000 \\
\hline $\begin{array}{l}\text { No. } 355 \text { Optimal Speed of Transition: Micro Evidence from the Czech } \\
\text { Republic }\end{array}$ & $\begin{array}{l}\text { Stepan Jurajda and Katherine } \\
\text { Terrell }\end{array}$ & Dec. 2000 \\
\hline No. 354 Political Instability and Growth in Dictatorships & $\begin{array}{l}\text { Jody Overland, Kenneth L. } \\
\text { Simons and Michael Spagat }\end{array}$ & Nov. 2000 \\
\hline No. 353 Disintegration and Trade & Jarko Fidrmuc and Jan Fidrmuc & Nov. 2000 \\
\hline $\begin{array}{l}\text { No. } 352 \text { Social Capital and Entrepreneurial Performance in Russia: A } \\
\text { Panel Study }\end{array}$ & Bat Batjargal & Dec. 2000 \\
\hline $\begin{array}{l}\text { No. 351 Entrepreneurial Versatility, Resources and Firm Performance in } \\
\text { Russia: A Panel Study }\end{array}$ & Bat Batjargal & Dec. 2000 \\
\hline $\begin{array}{l}\text { No. } 350 \text { The Dynamics of Entrepreneurial Networks in a Transitional } \\
\text { Economy: The Case of Russia }\end{array}$ & Bat Batjargal & Dec. 2000 \\
\hline $\begin{array}{l}\text { No. } 349 \text { R\&D and Technology Spillovers via FDI: Innovation and } \\
\text { Absorptive Capacity }\end{array}$ & Yuko Kinoshita & Nov. 2000 \\
\hline $\begin{array}{l}\text { No. } 348 \text { Microeconomic aspects of Economic Growth in Eastern } \\
\text { Europe and the Former Soviet Union, 1950-2000 }\end{array}$ & Sergei Guriev and Barry W. Ickes & Nov. 2000 \\
\hline $\begin{array}{l}\text { No. } 347 \text { Effective versus Statutory Taxation: Measuring Effective Tax } \\
\text { Administration in Transition Economies }\end{array}$ & $\begin{array}{l}\text { Mark E. Schaffer and Gerard } \\
\text { Turley }\end{array}$ & Nov. 2000 \\
\hline $\begin{array}{l}\text { No. } 346 \text { Objectives and Constraints of Entrepreneurs: Evidence from } \\
\text { Small and Medium Size Enterprises in Russia and Bulgaria }\end{array}$ & $\begin{array}{l}\text { Francesca Pissarides, Miroslav } \\
\text { Singer and Jan Svejnar }\end{array}$ & Oct. 2000 \\
\hline No. 345 Corruption and Anticorruption in the Czech Republic & $\begin{array}{l}\text { Lubomír Lízal and Evžen } \\
\text { Kočenda }\end{array}$ & Oct. 2000 \\
\hline No. 344 The Effects of Direct Foreign Investment & Jozef Konings & Oct. 2000 \\
\hline No. 343 On the Identification of Relative Wage Rigidity Dynamics & Patrick A. Puhani & Oct. 2000 \\
\hline $\begin{array}{l}\text { No. } 342 \text { The Determinants of Foreign Direct Investment in Transition } \\
\text { Economies }\end{array}$ & Alan A. Bevan and Saul Estrin & Oct. 2000 \\
\hline No. 341 The Global Spread of Stock Exchanges, 1980-1998 & Klaus Weber and Ge & Nov. 2000 \\
\hline $\begin{array}{l}\text { No. } 340 \text { The Costs and Benefits of Euro-isation in Central-Eastern } \\
\text { Europe Before or Instead of EMU Membership }\end{array}$ & D. Mario Nuti & Oct. 2000 \\
\hline No. 339 Debt Overhang and Barter in Russia & $\begin{array}{l}\text { Sergei Guriev, Igor Makarov and } \\
\text { Mathilde Maurel }\end{array}$ & Sept. 2000 \\
\hline $\begin{array}{l}\text { No. } 338 \text { Firm Performance and the Political Economy of Corporate } \\
\text { Governance: Survey Evidence for Bulgaria, Hungary, Slovakia and } \\
\text { Slovenia }\end{array}$ & $\begin{array}{l}\text { Patrick Paul Walsh and Ciara } \\
\text { Whela }\end{array}$ & July 2000 \\
\hline No. 337 Investment and Instability & $\begin{array}{l}\text { Nauro F. Campos and Jeffrey B. } \\
\text { Nugent }\end{array}$ & May 2000 \\
\hline $\begin{array}{l}\text { No. } 336 \text { The Evolution of the Insurance Sector in Central and } \\
\text { Eastern Europe and the former Soviet Union }\end{array}$ & Robert B.K. Pye & Aug. 2000 \\
\hline $\begin{array}{l}\text { No. } 335 \text { Institutional Technology and the Chains of Trust: Capital } \\
\text { Markets and Privatization in Russia and the Czech Republic }\end{array}$ & Bruce Kogut and Andrew Spicer & Aug. 2000 \\
\hline No. 334 The Evolution of Market Integration in Russia & $\begin{array}{l}\text { Daniel Berkowitz and David N. } \\
\text { DeJong }\end{array}$ & 2000 \\
\hline
\end{tabular}


No. 333 Efficiency and Market Share in Hungarian Corporate Sector No. 332 Search-Money-and-Barter Models of Financial Stabilization

No. 331 Worker Training in a Restructuring Economy: Evidence from the Russian Transition

No. 330 Economic Development in Palanpur 1957-1993: A Sort of Growth

No. 329 Trust, Organizational Controls, Knowledge Acquisition from the Foreign Parents, and Performance in Vietnamese International Joint Ventures

No. 328 Comparative Advertising in the Global Marketplace: The Effects of Cultural Orientation on Communication No. 327 Post Privatization Enterprise Restructuring No. 326 Who is Afraid of Political Instability?

No. 325 Business Groups, the Financial Market and Modernization No. 324 Restructuring with What Success? A Case Study of Russian Firms

No. 323 Priorities and Sequencing in Privatization: Theory and Evidence from the Czech Republic

No. 322 Liquidity, Volatility, and Equity Trading Costs Across Countries and Over Time

No. 321 Equilibrium Wage Arrears: A Theoretical and Empirical Analysis of Institutional Lock-In

No. 320 Rethinking Marketing Programs for Emerging Markets

No. 319 Public Finance and Low Equilibria in Transition Economies: the Role of Institutions

No. 318 Some Econometric Evidence on the Effectiveness of Active Labour Market Programmes in East Germany

No. 317 A Model of Russia's "Virtual Economy"

No. 316 Financial Institutions, Financial Contagion, and Financial Crises

No. 315 Privatization versus Regulation in Developing Economies: The Case of West African Banks

No. 314 Is Life More Risky in the Open? Household Risk-Coping and the Opening of China's Labor Markets

No. 313 Networks, Migration and Investment: Insiders and Outsiders in Tirupur's Production Cluster

No. 312 Computational Analysis of the Impact on India of the Uruguay Round and the Forthcoming WTO Trade Negotiations

No. 311 Subsidized Jobs for Unemployed Workers in Slovakia No. 310 Determinants of Managerial Pay in the Czech Republic

No. 309 The Great Human Capital Reallocation: An Empirical Analysis of Occupational Mobility in Transitional Russia

No. 308 Economic Development, Legality, and the Transplant Effect

No. 307 Community Participation, Teacher Effort, and Educational Outcome: The Case of El Salvador's EDUCO Program

No. 306 Gender Wage Gap and Segregation in Late Transition No. 305 The Gender Pay Gap in the Transition from Communism: Some Empirical Evidence

No. 304 Post-Unification Wage Growth in East Germany
László Halpern and Gábor Kőrösi S.I. Boyarchenko and S.Z. Levendorskii Mark C. Berger, John S. Earle and Klara Z. Sabirianova Peter Lanjouw

Marjorie A. Lyles, Le Dang Doanh, and Jeffrey Q. Barden

Zeynep Gürhan-Canli and Durairaj Maheswaran Morris Bornstein

Nauro F. Campos and Jeffrey B. $\quad$ July 2000 Nugent

Raja Kali

Susan Linz

June 2000

July 2000

Nandini Gupta, John C. Ham and

Jan Svejnar

Ian Domowitz, Jack Glen and

Ananth Madhavan

John S. Earle and Klara Z.

Sabirianova

Niraj Dawar and Amitava

Chattopadhyay

Daniel Daianu and Radu

Vranceanu

Martin Eichler and Michael

Lechner

R.E Ericson and B.W Ickes

Haizhou Huang and Chenggang

$\mathrm{Xu}$

Jean Paul Azam, Bruno Biais, and

Magueye Dia

John Giles

Abhijit Banerjee and Kaivan

Munshi

Rajesh Chadha, Drusilla K.

Brown, Alan V. Deardorff and

Robert M. Stern

Jan. C. van Ours

Tor Eriksson, Jaromir Gottvald

and Pavel Mrazek

Klara Z. Sabirianova

Daniel Berkowitz, Katharina

Pistor, and Jean-Francois Richard

Yasuyuki Sawada

May 2000

Mar. 2000

Oct. 2000

June 2000

June 2000

June 2000

May 2000

Mar. 2000

Feb. 2000

Apr. 2000

Mar. 2000

Mar. 2000

May 2000

May 2000

Oct. 2000

Feb. 2000

Stepan Jurajda

Nov. 1999

Andrew Newell and Barry Reilly

May 2000

May 2000

Jennifer Hunt

Nov. 1998 


\begin{tabular}{|c|c|c|}
\hline $\begin{array}{l}\text { No. } 303 \text { How Does Privatization Affect Workers? The Case of the } \\
\text { Russian Mass Privatization Program }\end{array}$ & Elizabeth Brainerd & May 2000 \\
\hline $\begin{array}{l}\text { No. } 302 \text { Liability for Past Environmental Contamination and } \\
\text { Privatization }\end{array}$ & Dietrich Earnhart & Mar. 2000 \\
\hline No. 301 Varieties, Jobs and EU Enlargement & $\begin{array}{l}\text { Tito Boeri and Joaquim Oliveira } \\
\text { Martins }\end{array}$ & May 2000 \\
\hline No. 300 Employer Size Effects in Russia & Todd Idson & Apr. 2000 \\
\hline $\begin{array}{l}\text { No. } 299 \text { Information Complements, Substitutes, and Strategic Product } \\
\text { Design }\end{array}$ & $\begin{array}{l}\text { Geoffrey G. Parker and Marshall } \\
\text { W. Van Alstyne }\end{array}$ & Mar. 2000 \\
\hline $\begin{array}{l}\text { No. } 298 \text { Markets, Human Capital, and Inequality: Evidence from Rural } \\
\text { China }\end{array}$ & $\begin{array}{l}\text { Dwayne Benjamin, Loren Brandt, } \\
\text { Paul Glewwe, and Li Guo }\end{array}$ & May 2000 \\
\hline No. 297 Corporate Governance in the Asian Financial Crisis & $\begin{array}{l}\text { Simon Johnson, Peter Boone, } \\
\text { Alasdair Breach, and Eric } \\
\text { Friedman }\end{array}$ & Nov. 1999 \\
\hline No. 296 Competition and Firm Performance: Lessons from Russia & J. David Brown and John S. Earle & Mar. 2000 \\
\hline No. 295 Wage Determination in Russia: An Econometric Investigation & $\begin{array}{l}\text { Peter J. Luke and Mark E. } \\
\text { Schaffer }\end{array}$ & Mar. 2000 \\
\hline $\begin{array}{l}\text { No. 294: Can Banks Promote Enterprise Restructuring?: Evidence From } \\
\text { a Polish Bank's Experience }\end{array}$ & John P. Bonin and Bozena Leven & Mar. 2000 \\
\hline No. 293: Why do Governments Sell Privatised Companies Abroad? & $\begin{array}{l}\text { Bernardo Bortolotti, Marcella } \\
\text { Fantini and Carlo Scarpa }\end{array}$ & Mar. 2000 \\
\hline $\begin{array}{l}\text { No. 292: Going Public in Poland: Case-by-Case Privatizations, Mass } \\
\text { Privatization and Private Sector Initial Public Offerings }\end{array}$ & Wolfgang Aussenegg & Dec. 1999 \\
\hline $\begin{array}{l}\text { No. 291: Institutional Technology and the Chains of Trust: Capital } \\
\text { Markets and Privatization in Russia and the Czech Republic }\end{array}$ & Bruce Kc & Mar. 1999 \\
\hline No. 290: Banking Crises and Bank Rescues: The Effect of Reputation & Jenny Corbett and. & Jan. 2000 \\
\hline $\begin{array}{l}\text { No. 289: Do Active Labor Market Policies Help Unemployed Workers } \\
\text { to Find and Keep Regular Jobs? }\end{array}$ & Jan C. van Ours & Feb. 2000 \\
\hline No. 288: Consumption Patterns of the New Elite in Zimbabwe & & Feb. 2000 \\
\hline $\begin{array}{l}\text { No. 287: Barter in Transition Economies: Competing Explanations } \\
\text { Confront Ukranian Data }\end{array}$ & $\begin{array}{l}\text { Dalia Marin, Daniel Kaufmann } \\
\text { and Bogdan Gorochowskij }\end{array}$ & Jan. 2000 \\
\hline $\begin{array}{l}\text { No. 286: The Quest for Pension Reform: Poland's Security through } \\
\text { Diversity }\end{array}$ & $\begin{array}{l}\text { Marek Góra and Michael } \\
\text { Rutkowski }\end{array}$ & Jan. 2000 \\
\hline No. 285: Disorganization and Financial Collapse & $\begin{array}{l}\text { Dalia Marin and Monika } \\
\text { Schnitzer }\end{array}$ & Oct. 1999 \\
\hline No. 284: Coordinating Changes in M-form and U-form Organizations & $\begin{array}{l}\text { Yingyi Qian, Gérard Roland and } \\
\text { Chenggang Xu }\end{array}$ & May 1999 \\
\hline $\begin{array}{l}\text { No. 283: Why Russian Workers Do Not Move: Attachment of Workers } \\
\text { Through In-Kind Payments }\end{array}$ & Guido Friebel and Sergei Guriev & Oct. 1999 \\
\hline No. 282: Lessons From Fiascos in Russian Corporate Governance & $\begin{array}{l}\text { Merritt B. Fox and Michael A. } \\
\text { Heller }\end{array}$ & Oct. 1999 \\
\hline $\begin{array}{l}\text { No. 281: Income Distribution and Price Controls: Targeting a Social } \\
\text { Safety Net During Economic Transition }\end{array}$ & $\begin{array}{l}\text { Michael Alexeev and James } \\
\text { Leitzel }\end{array}$ & Mar. 1999 \\
\hline $\begin{array}{l}\text { No. 280: Starting Positions, Reform Speed, and Economic Outcomes in } \\
\text { Transitioning Economies }\end{array}$ & William Hallagan and Zhang Jun & Jan. 2000 \\
\hline No. 279: The Value of Prominent Directors & $\begin{array}{l}\text { Yoshiro Miwa \& J. Mark } \\
\text { Ramseyer }\end{array}$ & Oct. 1999 \\
\hline No. 278: The System Paradigm & János Kornai & Apr. 1998 \\
\hline $\begin{array}{l}\text { No. 277: The Developmental Consequences of Foreign Direct } \\
\text { Investment in the Transition from Socialism to Capitalism: The } \\
\text { Performance of Foreign Owned Firms in Hungary }\end{array}$ & Lawrence Peter King & Sept. 1999 \\
\hline $\begin{array}{l}\text { No. 276: Stability and Disorder: An Evolutionary Analysis of Russia's } \\
\text { Virtual Economy }\end{array}$ & $\begin{array}{l}\text { Clifford Gaddy and Barry W. } \\
\text { Ickes }\end{array}$ & Nov. 1999 \\
\hline $\begin{array}{l}\text { No. 275: Limiting Government Predation Through Anonymous } \\
\text { Banking: A Theory with Evidence from China. }\end{array}$ & $\begin{array}{l}\text { Chong-En Bai, David D. Li, } \\
\text { Yingyi Qian and Yijiang Wang }\end{array}$ & July 1999 \\
\hline No. 274: Transition with Labour Supply & Tito Boeri & Dec. 1999 \\
\hline
\end{tabular}




\begin{tabular}{|c|c|c|}
\hline $\begin{array}{l}\text { No. 273: Sectoral Restructuring and Labor Mobility: A Comparative } \\
\text { Look at the Czech Republic }\end{array}$ & Vit Sorm and Katherine Terrell & Nov. 1999 \\
\hline $\begin{array}{l}\text { No. 272: Published in: Journal of Comparative Economics "Returns to } \\
\text { Human Capital Under the Communist Wage Grid and During the } \\
\text { Transition to a Market Economy" Vol. 27, pp. 33-60 } 1999 .\end{array}$ & $\begin{array}{l}\text { Daniel Munich, Jan Svejnar and } \\
\text { Katherine Terrell }\end{array}$ & Oct. 1999 \\
\hline $\begin{array}{l}\text { No. 271: Barter in Russia: Liquidity Shortage Versus Lack of } \\
\text { Restructuring }\end{array}$ & $\begin{array}{l}\text { Sophie Brana and Mathilde } \\
\text { Maurel }\end{array}$ & June 1999 \\
\hline $\begin{array}{l}\text { No. 270: Tests for Efficient Financial Intermediation with Application to } \\
\text { China }\end{array}$ & Albert Park and Kaja Sehrt & Mar. 1999 \\
\hline $\begin{array}{l}\text { No. 269a: Russian Privatization and Corporate Governance: What Went } \\
\text { Wrong? }\end{array}$ & $\begin{array}{l}\text { Bernard Black, Reinier Kraakman } \\
\text { and Anna Tarassova }\end{array}$ & May 2000 \\
\hline $\begin{array}{l}\text { No. 269: Russian Privatization and Corporate Governance: What Went } \\
\text { Wrong? }\end{array}$ & $\begin{array}{l}\text { Bernard Black, Reinier Kraakman } \\
\text { and Anna Tarassova }\end{array}$ & Sept. 1999 \\
\hline No. 268: Are Russians Really Ready for Capitalism? & Susan Linz & Sept. 1999 \\
\hline No. 267: Do Stock Markets Promote Economic Growth? & $\begin{array}{l}\text { Randall K. Filer, Jan Hanousek } \\
\text { and Nauro Campos }\end{array}$ & Sept. 1999 \\
\hline $\begin{array}{l}\text { No. 266: Objectivity, Proximity and Adaptability in Corporate } \\
\text { Governance }\end{array}$ & $\begin{array}{l}\text { Arnoud W.A Boot and Jonathan } \\
\text { R. Macey }\end{array}$ & Sept. 1999 \\
\hline $\begin{array}{l}\text { No. 265: When the Future is not What it Used to Be: Lessons from the } \\
\text { Western European Experience to Forecasting Education and Training in } \\
\text { Transitional Economies }\end{array}$ & $\begin{array}{l}\text { Nauro F. Campos, Gerard } \\
\text { Hughes, Stepan Jurajda, and } \\
\text { Daniel Munich }\end{array}$ & Sept. 1999 \\
\hline $\begin{array}{l}\text { No. 264: The Institutional Foundation of Foreign-Invested Enterprises } \\
\text { (FIEs) in China }\end{array}$ & Yasheng Huang & Sept. 1999 \\
\hline $\begin{array}{l}\text { No. 263: The Changing Corporate Governance Paradigm: Implications } \\
\text { for Transition and Developing Countries }\end{array}$ & and Ernst-Ludwig & June 1999 \\
\hline No. 262: Law Enforcement and Transition & d and Thierry & 999 \\
\hline $\begin{array}{l}\text { No. 261: Soft Budget Constraints, Pecuniary Externality, ar } \\
\text { Track System }\end{array}$ & Jiaht & June 2000 \\
\hline $\begin{array}{l}\text { No. 260: Missing Market in Labor Quality: The Role of Quality Markets } \\
\text { in Transition }\end{array}$ & $\mathrm{Ga}$ & July 1999 \\
\hline $\begin{array}{l}\text { No. 259: Do Corporate Global Environmental Standards in Emerging } \\
\text { Markets Create or Destroy Market Value }\end{array}$ & Stuart Hart and & June 1999 \\
\hline No. 258: Public Training and Outflows from Unemployment & Patrick A. Puhani & June 1999 \\
\hline $\begin{array}{l}\text { No. 257: Ownership Versus Environment: Why are Public Sector Firms } \\
\text { Inefficient? }\end{array}$ & Bartel and Ann E. & June 1999 \\
\hline $\begin{array}{l}\text { No. 256: Taxation and Evasion in the Presence of Exortion by } \\
\text { Organized Crime }\end{array}$ & $\begin{array}{l}\text { Michael Alexeev, Eckhard Janeba } \\
\text { and Stefan Osborne }\end{array}$ & Nov. 1999 \\
\hline No. 255: Revisiting Hungary's Bankruptcy Episode & $\begin{array}{l}\text { John P. Bonin and Mark E. } \\
\text { Schaffer }\end{array}$ & Sept. 1999 \\
\hline No. 254: FDI & V N Whit & 1999 \\
\hline $\begin{array}{l}\text { No. 253: The Asian Financial Crisis: What Happened, and What is to be } \\
\text { Done }\end{array}$ & $\begin{array}{l}\text { Jeffrey D. Sachs and Wing Thye } \\
\text { Woo }\end{array}$ & Jan. 1999 \\
\hline No. 252: Organizational Law as Asset Partitioning & $\begin{array}{l}\text { Henry Hansmann and Reinier } \\
\text { Kraakman }\end{array}$ & Sept. 1999 \\
\hline $\begin{array}{l}\text { No. 251: Consumer Behavior Research in Emerging Consumer Markets: } \\
\text { the Case of the Optimum Stimulation Level in South Africa }\end{array}$ & $\begin{array}{l}\text { dict E. M. Steenkamp } \\
\text { n M. Burgess }\end{array}$ & Sept. 1999 \\
\hline $\begin{array}{l}\text { No. 250: Property Rights Formation and the Organization of Exchange } \\
\text { and Production in Rural China }\end{array}$ & $\begin{array}{l}\text { Matthew A. Turner, Loren } \\
\text { Brandt, and Scott Rozelle }\end{array}$ & July 1998 \\
\hline $\begin{array}{l}\text { No. 249: Impacts of the Indonesian Economic Crisis: Price Changes and } \\
\text { the Poor }\end{array}$ & $\begin{array}{l}\text { James Levinsohn, Steven Berry, } \\
\text { and Jed Friedman }\end{array}$ & June 1999 \\
\hline $\begin{array}{l}\text { No. 248: Internal Barriers in the Transition of Enterprises from Central } \\
\text { Plan to Market }\end{array}$ & Charalambos Vlachoutsicos & July 1999 \\
\hline $\begin{array}{l}\text { No. 247: Spillovers from Multinationals in Developing Countries: the } \\
\text { Mechanisms at Work }\end{array}$ & Richard E. Caves & June 1999 \\
\hline
\end{tabular}

